Review

\title{
Species Comparison of the Role of p38 MAP Kinase in the Female Reproductive System
}

\author{
Zaher A. Radi ${ }^{1}$, Rosemary A. Marusak ${ }^{2}$, and Dale L. Morris ${ }^{1}$ \\ ${ }^{1}$ Drug Safety Research \& Development, Pfizer Global R\&D, 700 Chesterfield Parkway West, St. Louis, MO 63017, USA \\ ${ }^{2}$ North Carolina State University, Raleigh, NC 27606, USA
}

\begin{abstract}
The p38 mitogen-activated protein kinases (MAPKs) are members of discrete signal transduction pathways that have significant regulatory roles in a variety of biological processes, depending on the cell, tissue and organ type. p38 MAPKs are involved in inflammation, cell growth and differentiation and cell cycle. In the female reproductive system, p38 MAPKs are known to regulate various aspects of the reproductive process such as mammalian estrous and menstrual cycles as well as early pregnancy and parturition. p38 MAPKs have also been implicated in alterations and pathologies observed in the female reproductive system. Therefore, pharmacologic modulation of p38 MAPKs, and inter-connected signaling pathways (e.g., estrogen receptor signaling, c-fos, c-jun), may influence reproductive physiology and function. This article provides a critical, comparative review of available data on the roles of p38 MAPKs in the mammalian female reproductive system and in reproductive pathophysiology in humans and preclinical species. We first introduce fundamental differences and similarities of the mammalian female reproductive system that should be considered by toxicologists and toxicologic pathologists when assessing the effects of new pharmacologic agents on the female reproductive system. We then explore in detail the known roles for p38 MAPKs and related molecules in female reproduction. This foundation is then extended to pathological conditions in which p38 MAPKs are thought to play an integral role. (J Toxicol Pathol 2009; 22: 109-124)
\end{abstract}

Key words: p38 MAPK, female, reproduction

\section{Introduction}

The p38 mitogen activated protein kinases (MAPKs) are members of discrete signaling transduction pathways that play significant regulatory roles in a variety of biological processes including inflammation, cell differentiation, and cell growth ${ }^{1-4}$. By participating in phosphorylation cascades, p38 modulates the regulation and activity of several transcription factors (i.e., activating transcription factors-1 and -2 (ATF-1, ATF-2); the p53 tumor suppressor protein; and CCAAT/Enhancer Binding Proteins-beta $(\mathrm{C} / \mathrm{EBP} \beta)^{5-8}$. These transcription factors lead

Received: 1 March 2009, Accepted: 14 April 2009

Mailing address: Dr. Zaher A. Radi, Pfizer Global and Research

Development, St. Louis Laboratories, 700 Chesterfield Parkway West, Building BB371-2 (BB3N), St. Louis, MO 63017, USA

TEL: 1-636-247-1218 FAX: 1-636-247-1114

E-mail: zaher.radi@pfizer.com

Figures 4 and 6 of this paper are reprinted by permission of SAGE Publications, Inc., from the article "Comparative Expression and Distribution of $c$-fos, Estrogen Receptor $\alpha(E R \alpha)$ and p38 $\alpha$ in the Uterus of Rats, Monkeys, and Humans”, written by Radi ZA and Khan NK, which was originally published in Toxicologic Pathology, volume 34 , issue 4, pages 327-335, year 2006, copyright 2006 by the Society of Toxicologic Pathology (License Number, 2164861103708). to cytokine production, cell growth, apoptosis, and other cellular processes. Therefore, because of p38's involvement in inflammation, specific p38 inhibitors are under development as anti-inflammatory medicines ${ }^{3,9}$.

p38 MAPKs are activated by dual phosphorylation at residues thr180 and tyr182. Some p38 inhibitors (i.e., SB203580) compete for the ATP binding pocket and inhibit direct enzymatic activation, while other inhibitors (i.e., BIRB796) stabilize a conformation that is unable to bind $\mathrm{ATP}^{10}$.

p38 MAPK, along with a variety of intracellular signaling pathways such as Estrogen Receptor $\alpha(E R \alpha)$, cjun and c-fos, orchestrate physiological events in the uterus during the menstrual cycle in both humans and in preclinical species such as nonhuman primates (NHPs). Emerging data suggests that uterine function effects may be attributable to the close interrelationships of these signaling pathways and their modulation ${ }^{11}$. c-fos and c-jun interact with the transcription factor activator protein-1 (AP-1) which translocates to the nucleus and binds to the AP-1 enhancer element to initiate a cascade of gene induction events that lead to cell proliferation ${ }^{12}$. MAPKs regulate AP-1 transcriptional activity and c-fos expression in the uterus and mediates mechanical stretch-induced c-fos expression in myometrial smooth muscle cells ${ }^{13-16}$. 
Estrogen stimulates DNA synthesis, and cellular proliferation and differentiation in the uterus of mammals ${ }^{17,18}$. Binding of estrogen to its receptor (ER) contributes to uterine cellular proliferation via increased expression of immediate early response genes ${ }^{13,18-21}$. It has also been suggested that the initial steps in the mechanism of mitogenesis by estrogen involve activation of c-fos gene expression in the rat uterus, emphasizing the orchestrated effort of these molecules in directing uterine function ${ }^{19}$.

p38 MAPKs are thought to contribute to parturition ${ }^{15,22,23}$. Marked increases in the p38 kinase activity in the human uterus was observed on day 19 of gestation and during labor, and declined to the control levels post-delivery $^{23}$. p38 MAPK has also been shown to be present in endometriotic cells from humans and activated by pro-inflammatory agents ${ }^{24}$. Moreover, various aspects of the mammalian estrous and menstrual cycles, as well as early pregnancy, involve regulatory roles for p38 MAPKs ${ }^{5-8,25-28}$, and p38 MAPK has been implicated in alterations and pathologies observed in the female reproductive system 1,12,29. Considerable "cross talk" between the MAPK signaling pathways (e.g., p38, JUNK) may also play an important role throughout all stages of the female reproductive process.

Collectively, these observations imply a close interrelationship between ER, c-fos, c-jun, and p38 in modulating uterine function during the estrous cycle and early embryonic processes. Therefore, pharmacologic modulation of one or more of these signaling molecules, coupled with interspecies differences in uterine cyclicity, may influence uterine function. This article provides a critical, comprehensive review of the known roles for p38 MAPKs and related pathways in the mammalian female reproductive system in of humans and in preclinical species, and signaling in reproductive pathophysiology. We first introduce fundamental differences and similarities in the mammalian reproductive system in humans and in preclinical species. We then explore in detail the known roles for p38 MAPKs pathways in female reproduction. With this foundation, we then provide a review of the pathological conditions in the female reproductive system under which p38 MAPKs may play a role.

\section{Mammalian Estrous and Menstrual Cycles}

Much of our knowledge of the female reproductive cycle is drawn from research conducted on a variety of species. The rat, dog, and monkey are common laboratory animals used for testing new drug candidates developed for use in human medicine. However, there are significant differences among these preclinical species in the female reproductive system. Such differences should be taken into consideration by toxicologists and toxicologic pathologists when assessing the effects of new pharmacologic agents on the female reproductive system.

We first introduce these species differences in uterine cyclicity. The mechanism of early pregnancy trophoblast invasion is similar in rodents and the NHPs. The rat plays a prominent role in female reproduction research, making it a good model to detail the mammalian estrous cycle. There are significant interspecies differences in uterine cyclicity that may influence uterine functions and modulate the signaling pathways of MAPKs, c-fos, c-jun, and/or ER. For example, rats exhibit cyclic changes in the expression of cfos and $E R \alpha^{11}$. The comparative aspects of the estrous cycle in the rat and dog and menstrual cycle in NHPs and human are summarized in Table 1 and Figs. 1 and 2.

\section{Rat Estrous Cycle}

Rats are continuously polyestrus, with an average estrous cycle length of 4-5 days. The cycle is subdivided into four phases: proestrus (P), estrus (E), metestrus (M) (diestrus I), and diestrus II (D) ${ }^{30,31}$. The $\mathrm{P}$ phase begins when progesterone $\left(\mathrm{P}_{4}\right)$ levels decline as a result of luteolysis and follicle-stimulating hormone (FSH) and luteinizing hormone $(\mathrm{LH})$ secretion from the anterior pituitary. In the adult female rat, the concentrations of the preovulatory estradiol $\left(E_{2}\right)$, which is produced by ovarian follicles, peak during the $P$ phase (Fig. 1). As $E_{2}$ levels drop during the $E$ phase, there is a corresponding lack of glandular and luminal epithelial growth and, in parallel, an increased apoptosis in these cells. Stromal cell proliferation is also seen ${ }^{18}$. The uterine lumen is dilated during both the $\mathrm{P}$ and $\mathrm{E}$ phases. As a result of the preovulatory $\mathrm{E}_{2}$ surge, ovulation and mating behavior occur at the beginning of the $\mathrm{M}$ phase. Notably, of the cell types comprising the uterus (stromal, epithelial, and myometrial), only the epithelial cells proliferate in response to $E_{2}$ in the adult rat and mouse. However, all cell types respond in the immature rodent ${ }^{21}$. $\mathrm{P}_{4}$, produced by the newly formed ovarian corpora lutea, also begins to rise and reaches a maximum peak during the longest phase of the cycle: the $\mathrm{D}$ phase. During the $\mathrm{D}$ phase, epithelial cell division and maturation is inhibited, but due to lowered levels of $\mathrm{P}_{4}$ in the rat, typical endometrial gland secretion is not observed.

The histologic appearance of the uterus varies with the stage of the reproductive cycle. The $\mathrm{P}$ phase is characterized by distention of the uterine lumen with clear fluid and the lumen is usually lined by large low columnar cells ${ }^{31}$. Smooth muscle hypertrophy, endometrial stromal cell proliferation, stromal edema, proliferation of luminal and glandular epithelium, and a few mitotic figures are present during proestrus (Fig. 3A). In the E phase, the uterine lumen is lined by very large, tall columnar epithelium. There is myometrial hypertrophy, and many of the luminal and glandular epithelial cells undergo vacuolar degeneration and necrosis (Fig. 3B) ${ }^{30,31}$. In the $\mathrm{M}$ phase, the epithelial cells of the luminal lining are reduced in height, the stroma becomes denser, and mitotic activity decreases (Fig. 3C) ) $^{30,31}$. During the $\mathrm{D}$ phase, the uterus is quiescent and appears shrunken with dense endometrial stroma, atrophied myometrium, very small lumen, and cuboidal glandular and luminal epithelium.

Studies in several species have addressed the role of $\mathrm{P}_{4}$ in the modulation of $\mathrm{E}_{2}$ activity and maintenance of the 
Table 1. Comparative Aspects of the Estrous Cycle vs. Menstrual Cycle in Human and Animal Species (Days $\left.{ }^{1}\right)$

\begin{tabular}{|c|c|c|c|c|c|}
\hline & $\begin{array}{c}\text { Species } \\
\text { (Cycle length) }\end{array}$ & $\begin{array}{l}\text { Humans } \\
\text { (28 days) }\end{array}$ & $\begin{array}{c}\text { Primates } \\
\text { (28-30 days) }\end{array}$ & $\begin{array}{c}\text { Dog } \\
\text { (120 days) }\end{array}$ & $\begin{array}{c}\text { Rat } \\
\text { (96-120 hrs) }\end{array}$ \\
\hline \multirow[t]{10}{*}{ Cycle phases } & Proliferative (follicular) & 6 to 13 & 6 to 13 & -9 to 9 & -12 to $12^{2}$ \\
\hline & Secretory (luteal) & 14 to 28 & 14 to 28 & 10 to 56 & 34 to $88^{2}$ \\
\hline & Menses & 0 to 5 & 0 to 5 & NA & NA \\
\hline & Estrus & NA & NA & 0 to 9 & 0 to $12^{2}$ \\
\hline & Metestrus & NA & NA & NA & 12 to $33^{2}$ \\
\hline & Diestrus & NA & NA & 10 to 56 & 34 to $88^{2}$ \\
\hline & Anestrus & NA & NA & 57 to 198 & NA \\
\hline & Proestrus & NA & NA & 199 to 208 & 89 to $100^{2}$ \\
\hline & Ovulation & 14 to 15 & & 2 to 3 & 6 to $12^{2}$ \\
\hline & Luteolysis factor & Ovarian $\mathrm{PGF}_{2 \alpha}$ & Ovarian $\mathrm{PGF}_{2 \alpha}$ & Uterine $\mathrm{PGF}_{2 \alpha}$ & Uterine $\mathrm{PGF}_{2 \alpha}$ \\
\hline \multirow[t]{2}{*}{ Hormones } & Peak estrogen & 12 to 13 & 12 to 13 & $\mathrm{~A}, \mathrm{E}$ & $\mathrm{P}$ \\
\hline & Peak progesterone & 21 to 24 & 21 to 24 & $\mathrm{D}$ & $\mathrm{D}$ \\
\hline \multirow[t]{5}{*}{ Early pregnancy } & Receptivity & 20 to 24 & 20 to 24 & 3 to 6 & 72 to $120^{2}$ \\
\hline & Pregnancy recognition & 6 to 9 & 3 to 5 & 24 to 25 & $\begin{array}{l}\text { Post coitum several hrs } \\
\text { post ovulation }\end{array}$ \\
\hline & Pregnancy factor & HCG & HCG & None & PRL \\
\hline & Conceptus attachment & 23 to 26 & 23 to 26 & 16 to 18 & 120 to $144^{2}$ \\
\hline & Implantation & 7 to 9 & 21 to 23 & 18 to $20^{4}$ & 120 to $144^{2}$ \\
\hline Gestation & & $9^{3}$ & 5.3 to $5.6^{3}$ & 2.1 to $2.3^{3}$ & 0.7 to $0.8^{3}$ \\
\hline
\end{tabular}

Note the significant interspecies differences in uterine cyclicity. Such differences may influence uterine functions and pharmacologic

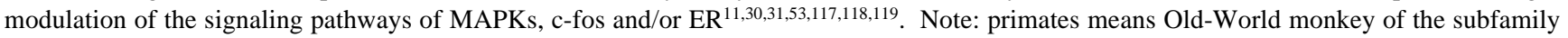
Cercopithecinae (macaques, baboons and their phylogenetic kin).

NA=Not applicable; $\mathrm{E}_{2}=$ Estrogen; $\mathrm{E}=$ Estrus; $\mathrm{A}=$ Anestrus; $\mathrm{P}=$ Proestrus; $\mathrm{P}_{4}=$ Progesterone; $\mathrm{D}=$ Diestrus; Mths=Months; hCG=Human chorionic gonadotropin; PRL=Prolactin-like hormones.

${ }^{1}$ All value ranges are provided in days, unless otherwise noted.

${ }^{2}$ Values expressed in hours.

${ }^{3}$ Values expressed in months.

${ }^{4}$ Implantation as such does not occur.

uterus in a state of quiescence or inactivity ${ }^{23-35} . \mathrm{P}_{4}$ is secreted for only a limited time by the rat, unless a leuteotropic signal from the pituitary is received ${ }^{36}$. In rats, that signal is prolactin, which is released upon cervical stimulation (copulation) ${ }^{37}$. With a new release of preimplantation $\mathrm{E}_{2}$ from the ovary, $\mathrm{P}_{4}$ stimulates glandular secretion, endometrial stromal cell proliferation, and myometrial transformation. Furthermore, luminal epithelial cells undergo differentiation while preparing to receive the blastocyst.

Interestingly, in the absence of pre-implantation $\mathrm{E}_{2}$ in pregnant rats at this time, $\mathrm{P}_{4}$ maintains the uterus in a neutral phase and the blastocyst in dormancy. Co-activators and repressors of steroid receptors govern appropriate $E_{2} / P_{4}$ synergism $^{38}$. For example, estrogen receptor (ER) negative uteri are hypoplastic, while $\mathrm{P}_{4}$ receptor negative uteri are hyperplastic. This stringent regulation is required for appropriate uterine receptivity and embryo implantation in many species ${ }^{39,40}$.

MAPK signaling pathways are activated during implantation in the rat ${ }^{41}$. Uterine receptivity, also known as the window of implantation, is identified by loss of progesterone (Pgr) gene expression from the epithelia ${ }^{42}$ and by expression of a number of extracellular matrix molecules (e.g., secreted phosphoprotein 1 or osteopontin) and integrin heterodimers (e.g. $\alpha \mathrm{V} \beta 3$ ) that also initiate p38 MAPK signaling ${ }^{40,43}$. If no embryo implantation follows, the uterine endometrium, via an oxytocin (OT)-mediated mechanism, produces excess prostaglandin (PG), particularly PGF $_{2 \alpha}$, which is received by the ovary. As a result, $\mathrm{P}_{4}$ production is decreased by the ovary and luteolysis occurs, marking the end of the $\mathrm{D}$ phase.

\section{Human and Nonhuman Primate Menstrual Cycle}

There are several benefits to using the NHP, in particular Old-World monkeys, in female reproduction studies $^{44,45}$. In general, NHP reproductive uterine and ovarian cycles and circulating steroid binding proteins, resemble those in humans, although other aspects (i.e., cycle length, gestation length) are different (Table 1). Our discussion draws upon both human and NHP studies, with species differences noted. For purposes of this review, NHP means Old-World monkey of the subfamily Cercopithecinae (macaques, baboons and their phylogenetic kin).

While the estrous and menstrual cycles have numerous 


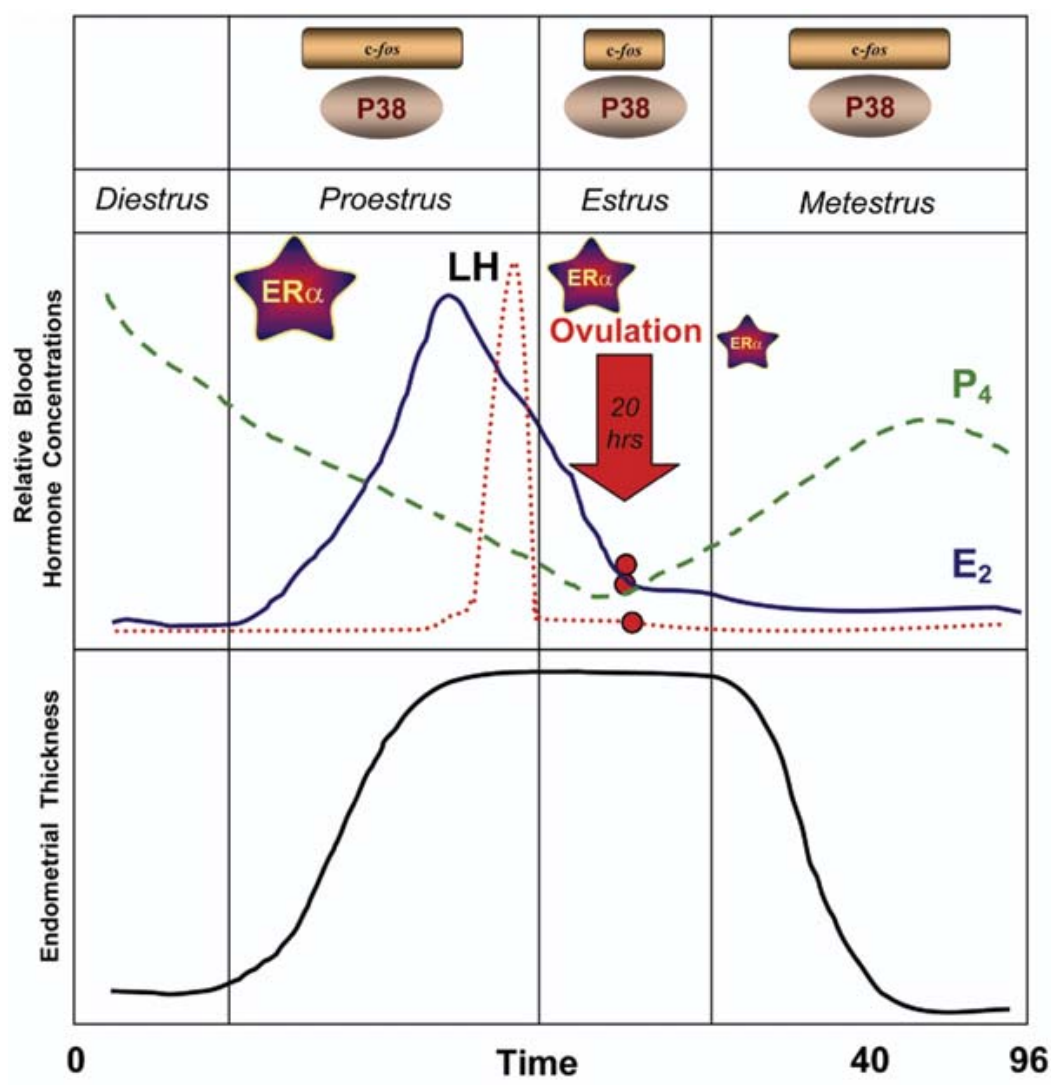

Fig. 1.

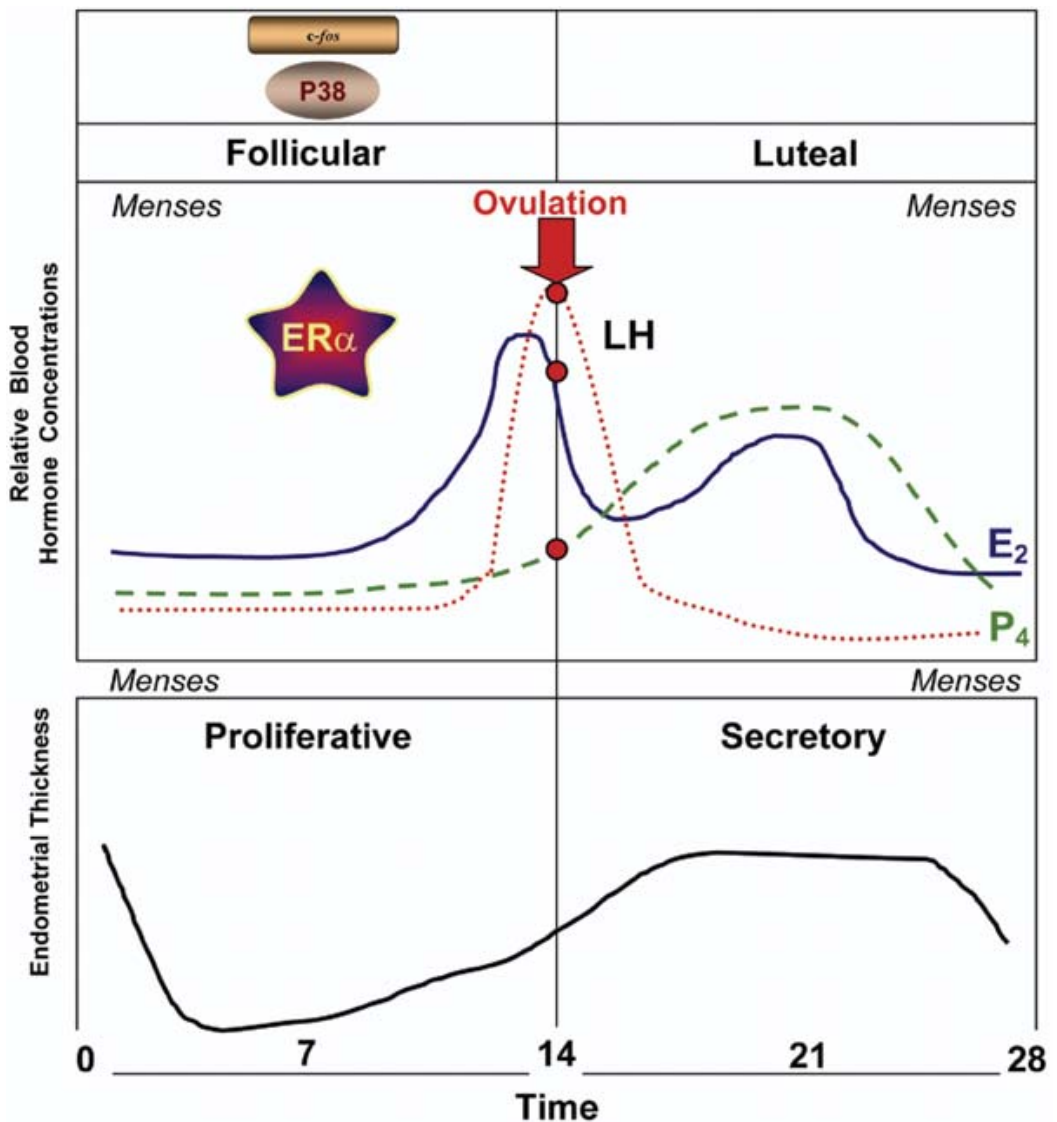

Fig. 2. 
similarities in humans and NHPs, a few primary differences or conventions should be noted (Table 1 ). In contrast to the estrous cycle, which begins and ends at E phase and/or ovulation, the menstrual cycle begins and ends at menses, with ovulation occurring mid-cycle. Also, while the estrous cycle uses follicular ( $\mathrm{P}$ and $\mathrm{E}$ phases) and luteal ( $\mathrm{M}$ and $\mathrm{D}$ phases) phases, the menstrual cycle is most commonly divided into proliferative (follicular) and secretory (luteal) phases, which describes endometrial thickness ${ }^{46}$. Note that the proliferative phase occurs prior to ovulation in the menstrual cycle, although further proliferation does take place at the beginning of the secretory phase. Finally, humans and NHPs slough their endometrium when conception does not occur, whereas in other mammals it is reabsorbed. During the proliferative phase the endometrium begins to thicken and growth of all endometrial cells (endothelial, myometrial and stromal) takes place (Fig. 2). Mitoses are present in the endometrial glandular epithelium during the follicular ("proliferative") phase of the cycle, and in the stroma during the early luteal ("secretory") phase. No evidence of mucus secretion or vacuolation is present during the proliferative phase. In the secretory phase, the endometrium slows its growth, stromal edema is evident, basal sub-nuclear secretory vacuoles are present in the glandular epithelium, and there is secretory exhaustion. Stromal edema is usually present at two times in the menstrual cycle, once in the mid-follicular/proliferative phase and once in the mid-luteal/secretory phase ${ }^{11}$.

However, the menstrual and estrous cycles have more similarities. During the follicular phase paralleling the $\mathrm{P}$ and E phases, follicle stimulating hormone (FSH) and luteinizing hormone (LH) are released from the anterior pituitary under hypothalamic control, leading to ovarian follicular recruitment for ovulation and increased $\mathrm{E}_{2}$ production. The endometrium thickens and $\mathrm{P}_{4}$ levels are minimal. The mature ovarian follicle eventually secretes sufficient $E_{2}$ to promote a LH surge, which culminates in ovulation. Growth of all endometrial cells (endothelial, myometrial and stromal) takes place in response to this $\mathrm{E}_{2}$ stimulation.

$\mathrm{P}_{4}$ levels increase in the stroma and remain elevated throughout the secretory phase, while levels in the epithelium decrease. The ruptured ovarian follicle develops into the corpus luteum and secretes $\mathrm{P}_{4}$ and $\mathrm{E}_{2}$ during the secretory phase. $\mathrm{P}_{4}$ suppresses $\mathrm{E}_{2}$ proliferation and causes a shift in proliferative activity to the stromal cells, which triggers epithelial cell differentiation in preparation for implantation.

The changing pattern of $\mathrm{E}_{2}$ and $\mathrm{P}_{4}$ secretion during the NHP menstrual cycle is essential for the hormonal regulation of endometrial growth and differentiation, and $\mathrm{P}_{4}$ action is essential for the proper maturation of the endometrium ${ }^{47}$. The transition from a proliferative ( $E_{2}$-dominated) to secretory $\left(\mathrm{P}_{4}\right.$-dominated) endometrium results in the appropriate differentiation that permits implantation ${ }^{47}$. In NHP, $\mathrm{P}_{4}$ primes the stromal cells to respond to preimplantation (nidatory) $\mathrm{E}_{2}$ for decidualization in early pregnancy. Stromal cell proliferation during the menstrual cycle is reported into the early to mid-secretory phase, when the endometrium reaches maximum thickness. Unlike the rat, $\mathrm{P}_{4}$ levels in humans and NHPs produce glandular secretory activity. A pre-decidualization process, manifested by stromal edema, can be seen, as early as 10 days following the LH surge in humans. The reaction is characterized by eosinophilic and enlarged stromal cells that begin to surround prominent spiral arteries. Over the subsequent 3-4 days, this reaction spreads to the upper two thirds of the endometrium ${ }^{48}$, preparing a suitable environment for embryo attachment, successful implantation, and protection from invasive trophoblasts of the mother. Notably, pre-decidualization is part of the normal human menstrual cycle and the late luteal phase of macaque endometrium show decidual changes ${ }^{48,49}$.

Fig. 1. Rat estrous cycle and differences in p38, c-fos and ER expression during various stages of the cycle. The average estrous cycle length in rats is $4-5$ days. The cycle is subdivided into four phases: proestrus, estrus, metestrus, and diestrus. The proestrus phase begins when progesterone $\left(\mathrm{P}_{4}\right)$ levels decline as a result of luteolysis and follicle-stimulating hormone (FSH) and luteinizing hormone (LH) secretion from the anterior pituitary. In the adult female rat, preovulatory estradiol $\left(E_{2}\right)$, which is produced by ovarian follicles, concentration peaks during the proestrus phase. As a result of the pre-ovulatory $E_{2}$ surge, ovulation occur during the estrus phase. In proestrus, endometrial stromal cell proliferation, stromal edema, and proliferation of luminal and glandular epithelium with subsequent increase in endometrial thickness take place. Myometrial hypertrophy also is seen during estrus. In the metestrus and diestrus phases, the luminal lining epithelial cells are reduced in height, the stroma becomes denser, and the uterus becomes quiescent with subsequent decreases in endometrial thickness. Overall, p38 strongly is upregulated during proestrus, estrus, and metestrus phases. c-fos is strongly upregulated in proestrus and metestrus and mildly upregulated in estrus. ER $\alpha$ expression is highest during proestrus and lowest in metestrus ${ }^{11,30,31,119}$.

Fig. 2. Human menstrual cycle and differences in p38, c-fos and ER expression during various stages of the cycle. The menstrual cycle begins and ends at menses, with ovulation occurring mid-cycle. The menstrual cycle is divided into proliferative (follicular) and secretory (luteal) phases, which describes endometrium thickness. During the follicular phase, follicle-stimulating hormone (FSH) and luteinizing hormone $(\mathrm{LH})$ release from the anterior pituitary under hypothalamic control, takes place and leads to ovarian follicular recruitment for ovulation and increased estradiol $\left(\mathrm{E}_{2}\right)$ production. The endometrium thickens and progesterone $\left(\mathrm{P}_{4}\right)$ levels are minimal. The mature ovarian follicle eventually secretes sufficient $\mathrm{E}_{2}$ to promote a $\mathrm{LH}$ surge, which culminates in ovulation. Growth of all endometrial cells (endothelium, myometrium and stroma) takes place in response to this $\mathrm{E}_{2}$ stimulation. During the proliferative phase, the endometrium begins to thicken and growth of all endometrial cells takes place. In the secretory phase, the endometrium slows its growth. Overall, p38, c-fos, and ER $\alpha$ are strongly upregulated during the proliferative phase and lack expression in the secretory phase $\mathrm{e}^{11,53,117}$. 

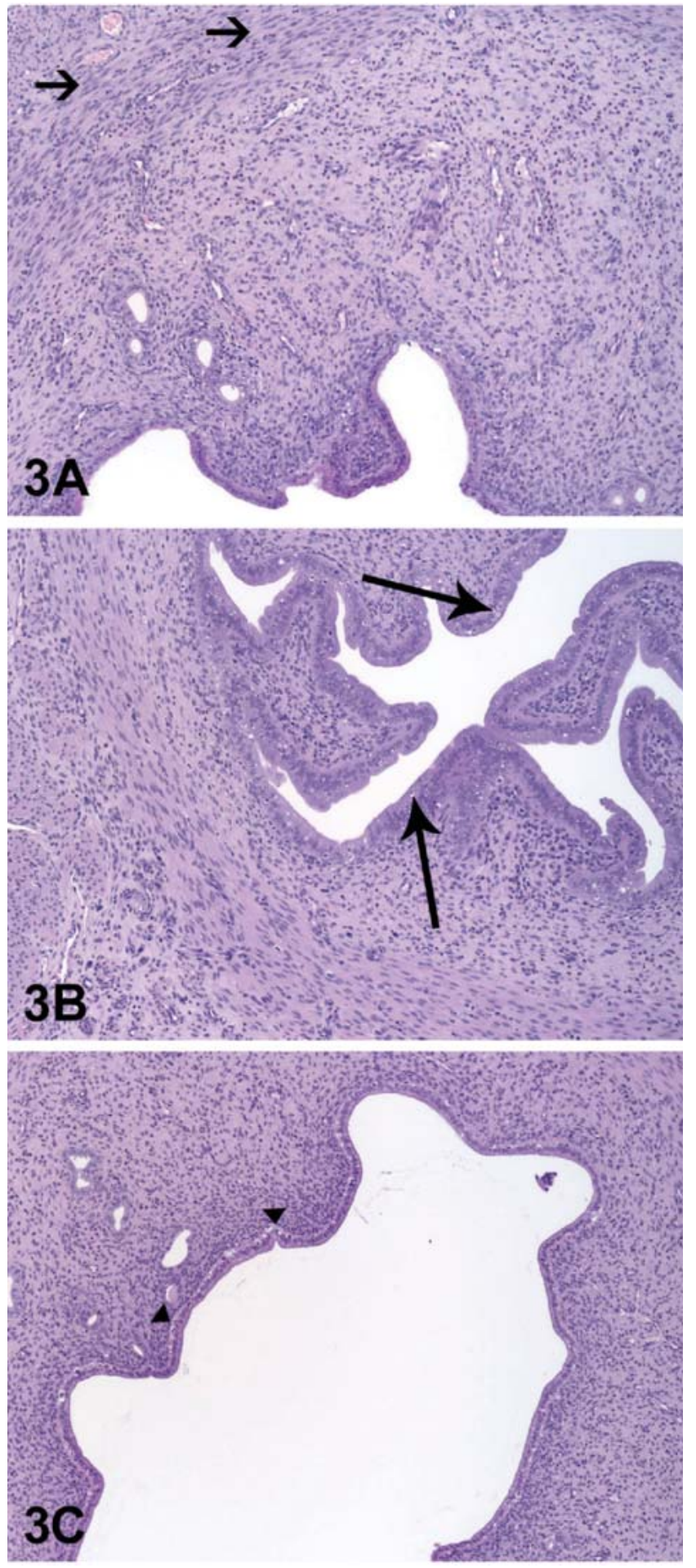

Fig. 3. Histological appearance of the rat uterus during proestrus (A), estrus (B), and metestrus (C). Smooth muscle hypertrophy (short arrows), endometrial stromal cell proliferation, stromal edema, and few mitotic figures are present during proestrus (A). In estrus (B), the uterine lumen is lined by very large, tall columnar epithelium, there is myometrial hypertrophy, and many of the luminal and glandular epithelial cells undergo vacuolar degeneration and necrosis (long arrows). In metestrus (C), the luminal lining epithelial cells are reduced in height, there is cytoplasmic vacuolation of luminal epithelial cells (arrowheads), the stroma becomes denser, and mitotic activity decreases.
In primates, the ovarian cycle is uterine independent whereas it is uterine dependent in subprimate mammals. Luteolysis is driven by the withdrawal of the ovarian steroids, $\mathrm{E}_{2}$ and $\mathrm{P}_{4}$, and release of $\mathrm{PGF}_{2 \alpha}$. $\mathrm{PGF}_{2 \alpha}$ is released by the uterus in rats and other mammals, and the ovaries in $\mathrm{NHPs}^{37}$. Mediation of this luteolytic event by OT, although controversial, is reported in the NHP and also thought to be important in the rat ${ }^{37,50}$, but appears unlikely to play a role in human menses ${ }^{48,49}$. Cytokines, proteases, and PGs also play a role in menses ${ }^{51,52}$.

\section{Role of p38 MAPK Signaling Throughout the Normal Estrous and Menstrual Cycles and Early Pregnancy}

As previously noted, p38 MAPKs are involved in cytokine and growth factor production, secretion and receptor signaling, cell growth and differentiation, and the cell cycle. All of these processes occur during normal uterine tissue cycling; therefore, it should not be surprising that p38 is expressed during both human menstrual and rat estrous cycles (Figs. 4A-F) ${ }^{11}$.

$\mathrm{PGF}_{2 \alpha}$ is a luteolytic factor during the normal cycling in large animal species, pseudopregnant rodents, and in the human and NHP menstrual cycle $\mathrm{e}^{30,53,54}$. However, there are species differences in their luteolytic dependence on OT and site of $\mathrm{PGF}_{2 \alpha}$ production (Table 1) ${ }^{37}$. Evidence for OT involvement in luteolysis at late $\mathrm{D}$ phase in ruminants is well established $^{37,55}$. By coupling to the $\mathrm{G}$ protein, OT promotes $\mathrm{PGF}_{2 \alpha}$ synthesis in a manner dependent on the ovarian steroids and their receptors. There is indirect and somewhat controversial evidence for the role of OT in $\mathrm{PGF}_{2 \alpha}$ production and luteolysis in the rat $^{37,55}$. However, OT receptor mRNA levels rise during the $\mathrm{D}$ phase in the rat uterus, reaching a maximum during the $\mathrm{P}$ phase, which emphasizes the importance of this receptor during the proliferative phase.

The mechanism of OT-induced PG synthesis has been investigated in rat OTR-transfected Chinese Hamster Ovary (CHO) cells ${ }^{56}$. It was found that there are two signaling pathways triggered by the OT-OTR complex ${ }^{56}$. Pathway (a) is $\mathrm{G}$ protein and cyclooxygenase (COX)-2-mediated and leads to PG synthesis through ERK2 MAPK, but not p38 MAPK activation. Similarly, $\mathrm{PGF}_{2 \alpha}$ production in sheep is shown to be ERK1/2-mediated. The parallel pathway (b), regulating free intracellular $\mathrm{Ca}^{2+}$ ion concentrations, involves coupling to the $\mathrm{Gi}$ protein and activation of p38 MAPK. Notably, a similar OT-OTR triggering event involving $\mathrm{Ca}^{2+}$ is reported to take place in the myometrium at the time of parturition in a variety of species. In contrast, regulatory events, especially those involving uterine sensitization to $E_{2}$ and $E R \alpha$, are thought to be different than those events seen during cycling ${ }^{55}$. In the rat and human, this OT-mediated parturition event is modulated by both $\mathrm{G}_{\mathrm{q}}$ - and $\mathrm{G}_{\mathrm{i}}$-coupling proteins. Thus, although the $\mathrm{PGF}_{2 \alpha}$-mediated luteolysis does not involve p38, other events involving $G_{i}-$ OTR coupling during the estrous cycle likely do involve p38. 

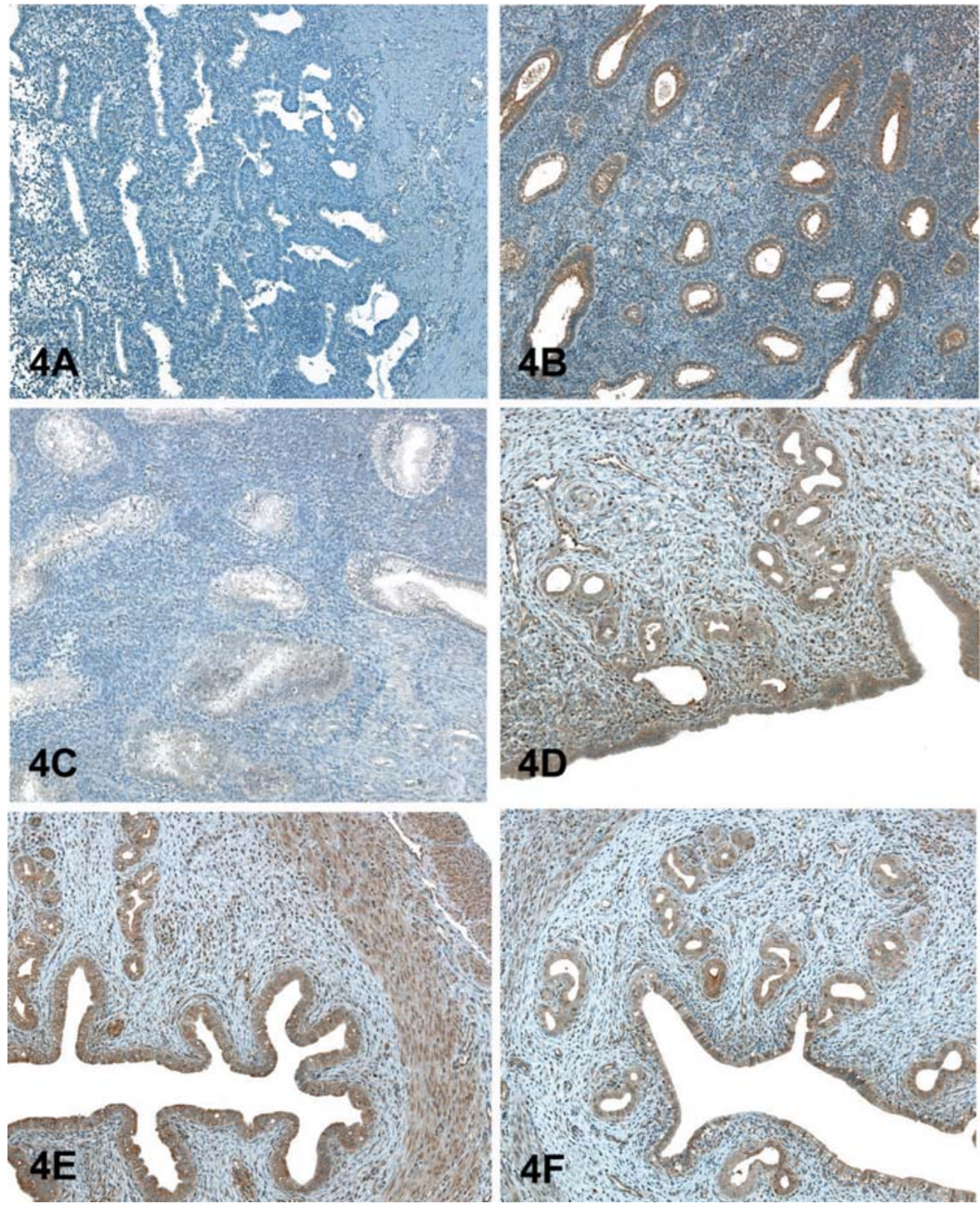

Fig. 4. (A) p38 expression in human uterus during the secretory phase. No epithelial p38 expression. (B) p38 expression in nonhuman primate (Cynomolgus macaque) uterus during the proliferative phase. Strong glandular epithelial cytoplasmic expression. (C) p38 expression in nonhuman primate (Cynomolgus macaque) uterus during the secretory phase. No epithelial expression. (D) p38 expression in rat uterus during proestrus. Strong glandular and luminal epithelial cytoplasmic expression. (E) p38 expression in rat uterus during estrus. Strong glandular and luminal epithelial cytoplasmic expression. Note strong myometrial smooth muscle cells cytoplasmic staining. (F) p38 expression in rat uterus during metestrus. Strong glandular and luminal epithelial cytoplasmic expression. Immunohistochemical stain, original magnification $\times 10$. Radi ZA, Khan NK, Toxicologic Pathology (34(4)), pp. 327-335, copyright 2006. Reprinted by Permission of SAGE Publications.

Extensive remodeling of the endometrium during the menstrual phase involves repeated tissue breakdown and regeneration ${ }^{7}$. During this time, leukocytes and endometrial cells secrete cytokines, chemokines, and proteases and also promote proliferation of endometrial cells, reepithelialization, and angiogenesis during reconstruction. These activities are modulated in the endometrium, in part, by the protease-activated receptor 2 (PAR2) via stimulation of IL-8 secretion in stromal and epithelial cells, which induce stromal cell proliferation and activate metalloprotease 7 in epithelial cells ${ }^{7}$. p38 and other MAPKs have been shown to mediate PAR2 activation and are therefore critical to the regulation of endometrial remodeling ${ }^{7}$. Furthermore, in the late secretory phase of the 
human menstrual cycle, as ovarian steroid levels decrease, superoxide dismutase (SOD) catalysis of the conversion of superoxide anion $\left(\mathrm{O}_{2}^{-}\right)$to hydrogen peroxide $\left(\mathrm{H}_{2} \mathrm{O}_{2}\right)$ decreases, which increases reactive oxygen species (ROS) ${ }^{51}$. Increased ROS production activates the nuclear factor kappa $\mathrm{B}(\mathrm{NF}-\kappa \mathrm{B})$, an inflammatory response transcription factor, which is thought to regulate COX-2 and subsequent synthesis of $\mathrm{PGF}_{2 \alpha}$. In rat skeletal muscle, it was shown that p38 inhibition impairs contraction-mediated IкB kinase

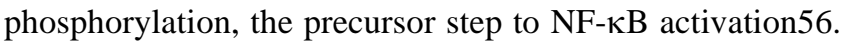
Translationally, it is plausible that p38 plays a role in NF- $\kappa B$ regulation of $\mathrm{PGF}_{2 \alpha}$ during luteolysis.

\section{$E_{2}$-Induced Endometrial Cell Proliferation and Possible Roles for p38 MAP Modulation: The $\mathrm{E}_{2^{-}}$ ER $\alpha$ complex}

Infertility and lack of uterotrophic response has been reported in $\mathrm{ER} \alpha$ knockout mice ${ }^{57}$. As previously noted, endometrial cell proliferation in the rat estrous cycle and NHP menstrual cycle is triggered by the release of $E_{2}$ from developing ovarian follicles. The ER is a zinc fingercontaining transcription factor and member of the nuclear receptor superfamily with two isoforms, $\alpha$ and $\beta$, which are differentially expressed in a tissue-dependent manner in the uterus and ovary, respectively ${ }^{58}$. In the uterus, $E_{2}$ binds to $\mathrm{ER} \alpha$. ER $\alpha$ is then targeted to the nucleus where it stimulates the growth of normal and transformed endometrial cells of the female reproductive system (Fig. 5). To facilitate this activity, ER $\alpha$ is localized in nuclei of uterine cells in a variety of species ${ }^{11,59,60}$.

Although $\mathrm{ER} \alpha$ predominates over its $\mathrm{ER} \beta$ analog, $\mathrm{ER} \beta$ mRNA and $\operatorname{ER} \beta$ protein are expressed in the nuclei of glandular epithelium in rats, macaques, and humans, suggesting a possible role for this isoform in modulating $\mathrm{E}_{2}$ action $^{61,62}$. Furthermore, nuclear receptors are not the only the key mediators in the female reproductive system. Nongenomic membrane ERs, upon $\mathrm{E}_{2}$ binding, can also induce G-protein activation and MAPK pathways important to cellular processes (Fig. 5) ${ }^{63-65}$.

During the proliferative phase of the menstrual cycle, ER $\alpha$ mRNA and protein are expressed in all major uterine cells, including glandular epithelial, stromal, and uterine wall smooth muscle cells (Fig. 6A). Protein concentrations of both receptors decline during the secretory phase ${ }^{59}$. Similarly in the adult rat, ER $\alpha$ expression is lowest during the $\mathrm{P}$ and $\mathrm{E}$ phases, and consistent with cell proliferation patterns, ER $\alpha$ is only expressed in the glandular and luminal epithelia (Fig. 6B). ER $\alpha$ concentration rises significantly in these cells during the $M$ phase in response to $E_{2}$ release ${ }^{18,62}$.

In the luminal epithelial cells, proliferation continues to rise and although $\mathrm{ER} \alpha$ levels drop, $\mathrm{ER} \beta$ in uterine glandular epithelium of the rat is debatable ${ }^{18,62}$. In NHP uterine sections, strong endometrial stromal cell nuclear ER $\alpha$ staining, moderate to strong glandular epithelial nuclear staining, and mild luminal epithelial and myometrial smooth muscle cell nuclear staining were seen during the proliferative phase (Fig. 6C) ${ }^{11}$.

During the secretory phase, mild glandular epithelial nuclear staining, negative myometrial smooth muscle cell and luminal epithelial nuclear staining, and strong endometrial stromal cell staining are observed. The changing pattern of $\mathrm{E}_{2}$ and $\mathrm{P}_{4}$ secretion during the NHP menstrual cycle is essential for the hormonal regulation of endometrial growth and differentiation and $\mathrm{P}$ action is essential for the proper maturation of the endometrium ${ }^{47}$. The transition from a proliferative $\left(E_{2}\right.$-dominated) to secretory ( $\mathrm{P}_{4}$-dominated) endometrium results in the appropriate differentiation that permits implantation ${ }^{47}$. The numbers of ER in non-human primate endometrium are low when serum $\mathrm{P}_{4}$ levels are elevated during the secretory phase of the menstrual cycle, but rise two to three fold when P4 levels decline during the proliferative phase ${ }^{66}$. In humans, extracellular signal-regulated kinase 1 (ERK1) is weakly expressed in glandular cells, but nearly undetectable in stromal cells of endometrial sections. ERK2 exhibited distinct glandular expression in both the proliferative and secretory phases, and a weak stromal cell expression ${ }^{67}$.

The mechanism of $E_{2}$ cell growth stimulation in the uterus is mediated through the expression of a series of genes (Fig. 5). Unlike other ligand-dependent receptors (e.g., glucocorticoid receptor), translocation back into the cytosol is not observed upon $\mathrm{E}_{2}$ binding ${ }^{62}$, although it is interesting to note that other non-classical ligands (e.g., the ER $\alpha$ antagonist, ICI 182,780) can translocate $\mathrm{ER} \alpha$ to the cytoplasm via a p38-mediated mechanism ${ }^{68}$.

The ligand binding region of ER $\alpha$ has two transactivating domains, which are thought to act cooperatively. These are $\mathrm{E}_{2}$-independent activation function (AF1) and $\mathrm{E}_{2}$-dependent AF2 domain, located in the $\mathrm{N}$ - and C-terminal regions, respectively ${ }^{69}$. When $\mathrm{E}_{2}$ binds to the AF2 region, a conformational change occurs that permits receptor binding to co-activating proteins (and corepressors) that are necessary for transcription. Some of these co-activators include estrogen receptor-associated protein 160 (ERAP160), a splice variant of the progesterone receptor (PR) co-activator steroid receptor coactivator-1 (SRC-1) and member of the p160/SRC-type steroid receptor co-activators, and CBP/p300, a known co-activator of the nuclear receptor transcription factors cyclic adenosine monophosphate (cAMP) response element-binding protein (CREB) and activating protein-1 (AP-1 $)^{70}$.

The $\mathrm{E}_{2}$-independent AF1 domain is thought to be responsible for tissue and target specificity of the receptor molecule. AF1 activation, also leading to co-activator recruitment, is accomplished by MAPK phosphorylation. Importantly, direct phosphorylation and activation of ER $\alpha$ by p38 has been shown in human uterine endometrial cancer cells, suggesting that a similar mechanism is expected to play a role in normal uterine cell proliferation ${ }^{69}$. MAPKs have also been shown to phosphorylate $E R \alpha^{71,72}$ and other nuclear hormone receptors containing AF1 and AF2 domains (e.g., peroxisomal proliferators activated receptor $[$ PPAR- $\gamma])^{73}$, thereby modulating their activity. 


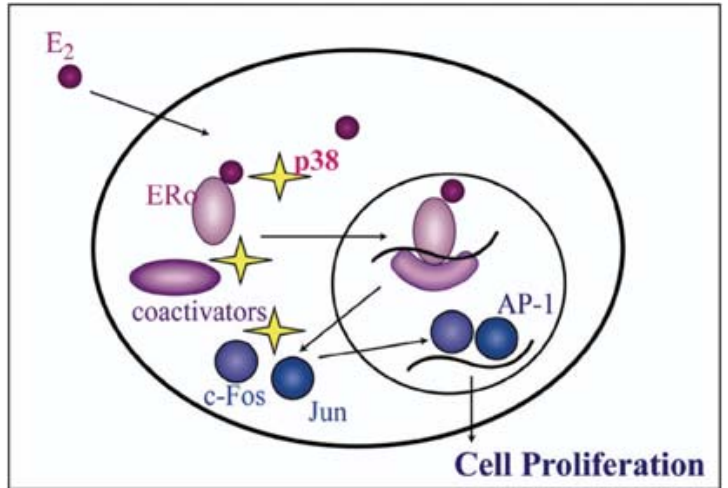

Fig. 5. $E_{2}-E R \alpha$ complex mediate cell proliferation via-p38-mediated mechanism. ER $\alpha$ nuclear receptors are only one of the key actors in the female reproductive system; non-genomic membrane ERs, upon $\mathrm{E}_{2}$ binding, can also induce G-protein activation and MAPK pathways important to cell processes such as cellular proliferation.

By binding to estrogen response elements (ERE), the nuclear $E_{2}-E R \alpha$ transcription complex enhances the expression of genes (i.e., PR, OT, OTR) and protooncogenes (i.e., c-fos, jun [c-jun, jun-B and jun-D] and c-myc) ${ }^{18,19}$, regulates other non-ERE factors (i.e., epidermal growth factor (EGF), insulin-like growth factor (IGF-1) and their respective receptors, and cyclin D1, a first acting cyclin in cell cycle regulation and intra-cellular sensor of extracellular signals $)^{74}$.

\section{Expression and localization of $E_{2}-E R \alpha$, c-fos, c- jun, and c-myc in Rat and Human Uteri}

Depending on the tissue type, the nuclear protooncogenes are key players in cell proliferation, differentiation, and tumorigenesis, due in part to the direct effect of $E_{2}$ on these genes and their direct regulation by p38 $\mathrm{MAPK}^{75}$. $\mathrm{E}_{2}$-ER $\alpha$ transcription products, c-Fos and c-Jun, are members of the AP-1 transcription factor complex. Because increased expression occurs early in $\mathrm{E}_{2}$ signaling, these genes are called "immediate early genes". Notably, and as it will be discussed, there are differences in protooncogene expression between primates and other species during the menstrual cycle.

Following $\mathrm{E}_{2}$ treatment in mice, c-fos expression is observed only in the glandular and luminal epithelia, signifying a cell specific proliferative role ${ }^{76}$. Mendoza et al. further detailed c-fos expression in the rat, reporting a rise and peak in c-fos mRNA in both the glandular and luminal epithelia during the $\mathrm{M}$ phase, with a drop in concentration in both cells during the D phase. While c-fos protein concentrations rise during the $\mathrm{M}$ phase, concentrations increase only slightly during the D phase ${ }^{18}$. The rate of c-fos gene expression parallels that of formation of the active nuclear $E_{2}$-ER $\alpha$ complex ${ }^{19}$. Studies in p300/CBP-associated factor $(\mathrm{PCAF})^{-/-} / \mathrm{PCAF}^{-\mathrm{B}^{+/-}}$knockout mice have pinpointed
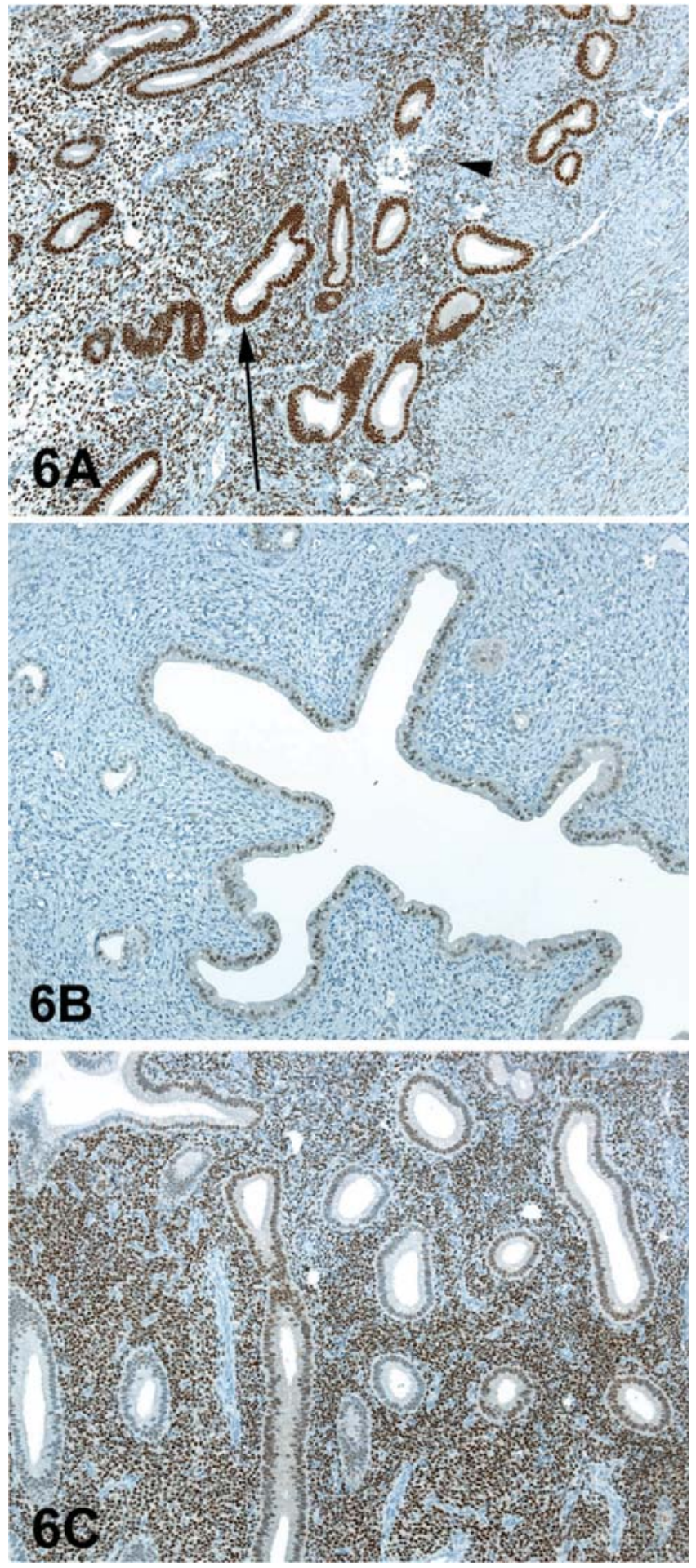

Fig. 6. A. ER $\alpha$ expression in human uterus during the proliferative phase. Strong glandular (long arrow) epithelial nuclear expression. Note strong interstitial and moderate smooth muscle cell nuclear ER expression (arrowheads). B. ER $\alpha$ expression in rat uterus during estrus. Moderate glandular and luminal epithelial nuclear expression. C. ER $\alpha$ expression in non-human primate (Cynomolgus macaque) uterus during the proliferative phase. Strong endometrial stromal cell nuclear expression and moderate glandular epithelial nuclear staining. Immunohistochemical stain, original magnification $\times 10$. Radi ZA, Khan NK, Toxicologic Pathology (34(4)), pp. 327-335, copyright 2006. Reprinted by Permission of SAGE Publications. 
the involvement of $E_{2}-E R \alpha$ co-activators p300/CBP and PCAF in mediating c-fos expression in normal uterine cell growth $^{76}$.

$\mathrm{P}_{4}$ appears to have more effect on c-fos mRNA than on the c-fos protein, a finding also reflected in the mouse ${ }^{75}$. Therefore, it is suggested that c-fos may have a role in the implantation period.

Similarly c-myc mRNA has been shown to rapidly increase in response to $E_{2}$ in the rat $^{19}$, with more specific distribution details described in the mouse ${ }^{77}$. Following $E_{2}$ injection in ovariectomized mice, c-myc protein was detected in uterine luminal and glandular epithelial nuclei during the $\mathrm{P}$ phase. $\mathrm{P}_{4}$ also increased the number of c-myc positive stromal cells. Moreover, c-myc was detected in the nuclei of luminal and glandular epithelial cells during proestrus and on days 1 and 2 of pregnancy. These results suggest c-myc is a potent stimulator of cell proliferation ${ }^{19}$.

In further contrast to c-fos and c-myc, c-jun is repressed by the ER in the rat epithelium ${ }^{20,21}$. c-jun expression was decreased in the epithelium and became evident in the stromal and myometrial cells early after $E_{2}$ stimulation in ovariectomized mice ${ }^{75}$. This work suggests that other Jun proteins (i.e., Jun-B, Jun-D) and c-fos may be important in early epithelial cell proliferation in the rodent.

As might be expected from animal model studies, $\mathrm{E}_{2}$ stimulates c-fos mRNA expression in the human endometrial epithelium and stroma during the proliferative phase of the menstrual cycle and occasionally during the mid-secretory phase ${ }^{78,79}$. Additionally, ER $\alpha$-dependent cfos expression in decidual tissue during pregnancy is very low, paralleling the decline of ER $\alpha$ in these cells and providing further evidence on the relationship between c-fos and $\mathrm{ER} \alpha$.

c-myc is also expressed in the human endometrium during the menstrual cycle. Unlike in the rat, c-jun expression is strongly detected in both the proliferative and secretory phases of the menstrual cycle in humans ${ }^{79}$. Bircan et al. showed, using immunohistochemistry, that c-jun expression occurs primarily in the proliferative phase of the menstrual cycle ${ }^{80}$, which was further supported by Hong et al. showing a correlation between growth in cultured endometrial stromal cells and activated c-jun expression ${ }^{81}$.

AP-1 subunits are dimeric basic region-leucine zipper (bZIP) proteins that belong to the Jun (c-jun, Jun-B and JunD), Fos (c-fos, Fos-B, Fra-1 and Fra-2), ATF (ATFa, ATF-2 and ATF-3), Maf, and Jun dimerization partner (JDP) subfamilies and recognize either phorbol-myristate-acetate (TPA)-response elements (TREs) or cAMP response elements (CRE) of DNA. Both Fos and Jun can act independently as transcription factors, activating transcription of growth-promoting genes or inhibiting growth-repressing gene transcription ${ }^{82}$.

AP-1 regulation of cell processes (i.e., proliferation, survival, differentiation) is dependent on dimer composition, cell stimulus, cell type, and cell environment. MAPKs, such as p38, contribute to AP-1 regulation by stabilizing the participating proteins through phosphorylation and regulating their induction ${ }^{82,83}$. For the latter, p38 has been shown to phosphorylate and activate cis-element binding proteins important for c-fos induction, including CREB or ATF (2), which occupy the CRE consensus sequence and ELK-1, a monomeric ternary complex factor (TCF). This TCF is recruited by the serum-response factor (SRF), the protein that recognizes the serum response element (SRE) in response to ultraviolet (UV) irradiation and interleukin-1 (IL-1) stimuli. It is therefore hypothesized that p38 may play a similar role in AP-1 regulation in uterine cell proliferation.

Cell cycle regulation is carried out by cyclins that bind to cyclin-dependent kinases (cdks) or cdk inhibitors to regulate phosphorylation of the retinoblastoma protein (pRB) and cell cycle progression. Studies in the murine system have suggested that a central point of regulation involves $\mathrm{E}_{2}$-induced uterine epithelial cell proliferation by nuclear accumulation of Cyclin D1 and pRB activation via a PI3 kinase/AKT/GSK3 $\beta$ - mediated pathway, which is inhibited by $\mathrm{P}_{4}{ }^{84}$. However, these studies also note the need for a parallel pathway to initially trigger DNA synthesis. Correspondingly, the c-jun protein product of $E_{2}-E R \alpha$ transcription is known to promote DNA synthesis, or the $\mathrm{S}$ phase of the cell cycle, in cultured normal human endometrial glandular cells via binding to the AP-1 sequence, with subsequent activation of Cyclin D1 ${ }^{85}$. Many other factors have been shown to play a role in Cyclin D1 regulation in other systems in response to the $E_{2}-E R \alpha$ interaction, including CREB, ATF-2, c-fos and pS1 in breast cancer cells. These studies reveal a host of complex signalling pathways that are most likely triggered upon $\mathrm{E}_{2}$ and $\mathrm{P}_{4}$ stimulation. Several pathways can involve p38 MAPK activation.

\section{Role of p38 MAPK Signaling in Stromal Cell Differentiation and Proliferation During Normal Menstrual Cycling and Early Pregnancy}

The purpose of cell proliferation upon $\mathrm{E}_{2}$ exposure is to prepare the uterus for embryo implantation where $\mathrm{P}_{4}$ and its progesterone receptor (PR) are critical. During the primate menstrual cycle, PR levels increase in the stroma during the proliferative phase and remain high during the secretory phase, while levels in the epithelium decrease with increasing $\mathrm{P}_{4}$ and during the secretory phase. Thus, $\mathrm{P}_{4}$ suppresses $\mathrm{E}_{2}$-modulated proliferation via $\mathrm{ER} \alpha$ and causes epithelial cells to differentiate in preparation for implantation. Persistence or overexpression of ER $\alpha$, is associated with implantation failure and other disorders ${ }^{39}$.

Fazleabas' group has detailed early conception in the non-human primate, describing three phases of uterine receptivity ${ }^{86}$. Phase $\mathrm{I}$ of early pregnancy, regulated by $\mathrm{E}_{2}$ and $\mathrm{P}_{4}$, is characterized histologically by the presence of columnar epithelium with microvilli and an increase in stromal cell proliferation. There is a loss of ER $\alpha$ and PR in the luminal and glandular epithelium, among other significant endometrial changes. Loss of receptors for estrogen and progesterone in uterine epithelia is a 
prerequisite for implantation and maintenance of pregnancy ${ }^{87}$. Phase II is induced by blastocyst signaling and is characterized by endometrial changes not observed in the absence of the blastocyst. In Phase III, blastocyst attachment and implantation occurs. Glandular hypertrophy, increased permeability of subepithelial capillaries, and stromal cell decidualization are initiated by the attachment reaction and are accomplished, in part, by expressed extracellular matrix proteins.

Pinipode formation characterizes the receptive endometrium or "implantation window"; and implantation occurs during the luteal phase (approximately day 21) of the menstrual cycle (Table 1$)^{88}$. In NHPs, in response to embryo signaling, $\mathrm{P}_{4}$ primes the stromal cells to respond to preimplantation (nidatory) $\mathrm{E}_{2}$ for decidualization in early pregnancy. It has been proposed that NHPs, especially macaques, may be a valuable experimental animal model to test the functional role of progesterone-regulated genes on endometrial receptivity ${ }^{89}$. A study on isolated normal and endometriotic stromal cells showed normal expression of p38, ERK, and JNK MAPKs, and an increase in p38 MAPK phosphorylation rate, when stimulated with IL-1 $\beta^{12}$. It has been demonstrated in an endometriosis murine model that a p38 inhibitor, FR 167653, suppresses the development of endometriosis ${ }^{90}$. This finding suggests an important regulatory role for p38 in endometrial cell growth. Indeed, a modulatory role for p38 in human endometrial stromal cell differentiation and proliferation in the uterus has been reported $^{81}$. Growth factors from uterine stromal cells regulate the uterine epithelia, and many of them (e.g., fibroblast growth factors- 7 and -10 , hepatocyte growth factor) signal via p38 MAPK $^{87}$.

Another potential role for p38 may be in the regulation of the p53 protein, a known substrate for p38 evidenced to be involved in decidualization of the endometrial stroma critical for embryo implantation ${ }^{2}$. The p53 protein is massively upregulated and sustained during cAMP-induced decidualization of cultured human endometrial stromal cells, and expressed in vivo in the stroma during the late secretory phase of the cycle ${ }^{6}$.

Successful implantation requires complete stromal cell decidualization. As described in human tissue, fibroblastlike mesenchymal cells differentiate into polygonal decidual cells that express new proteins such as the insulin-like growth factor binding protein-1 (IGFBP-1) and prolactin ${ }^{91}$. Species differ in embryonic signaling for the onset of decidualization (Table 1).

Type I and/or type II interferons (IFNs) are important in establishing uterine receptivity to implantation in mammals ${ }^{87}$. In ruminants, the pregnancy recognition signal, interferon tau (IFNtau), a type I interferon, prevents luteolysis by inhibiting the expression of $E R \alpha$ and subsequently OTR ${ }^{92}$. It has been shown in bovine endometrial cells that IFNtau induces the activation of p38, implicating a role for this MAPK in establishing and maintaining pregnancy ${ }^{93}$.

In the NHP, the release of chorionic gonadotropin (CG) rescues the corpus luteum and begins preparing the uterus for implantation. CG binds to its receptor in the primate endometrial epithelial cells and has been shown to induce phosphorylation of the ERK1/2 MAPKs, leading to expression of COX-2 mRNA and PGE production $^{86}$. CG along with the appropriate $\mathrm{P}_{4} / \mathrm{E}_{2}$ ratio, only initiates the process; decidualization is completed through an inflammatory-like response with the release of numerous cytokines.

An important and well-studied cytokine, expressed throughout the menstrual cycle, is Interleukin-1 (IL-1 $\alpha$ or IL-1 $\beta$ ). The expression of its receptor, IL-1 receptor type I, is low during the proliferative phase, moderate during ovulation and implantation, and peaks at the end of the cycle $^{94}$. Along with macrophages and uterine epithelial cells, trophoblast release IL-1, continuing, in the case of humans, or beginning, in the case of NHP, decidualization of stromal cells in early pregnancy ${ }^{91}$.

IL- $1 \beta$ is a major secretory product of the conceptus and establishment of pregnancy in pigs ${ }^{95}$. Following IL-1 $\beta$ stimulation, a COX-2 pathway leads to $\mathrm{PGE}_{2}$ synthesis, and is mediated by the p38 MAPK pathway. The IL-1-p38 mechanism noted above may be similar in other species, since both $\mathrm{PGE}_{2}$ and $\mathrm{PGF}_{2 \alpha}$ are known to induce decidualization in other hormonally-primed species, including the mouse and rat $^{96,97}$.

$\mathrm{PGE}_{2}$ is known to play a role in endometrial vascular permeability, one of the first responses to blastocyst implantation. In the rat, vascular permeability, in response to $\mathrm{PGE}_{2}$, occurs prior to stromal cell decidualization ${ }^{98}$. Cyclooxygenases have a pathophysiologic role in various systems in the body ${ }^{99}$. In the murine model, COX-2 was shown to be important during ovulation, fertilization, implantation, and decidualization ${ }^{100}$. p38 MAPK has been shown to be crucial to COX-2 expression and the nuclear hormone receptor PPAR $\delta^{25}$. Expression of COX-2 in the human endometrium by Prokineticin 1 (PROK1), a recently described protein that can modulate the inflammatory process, is dependent on activation of the Gq-phospholipase C-beta-cSrc-epidermal growth factor receptor-MAPK/ERK kinase pathway ${ }^{101}$. Blocking the COX-2 pathway by inhibiting p38 MAPK blunts expression of PPAR $\delta$ and decreases the decidualization reaction. Interestingly, downstream from p38 activation are the ATF, CREB, and C/ EBP factors; known co-activators of the ER $\alpha$ and cis elements of c-fos, and may be a link between $\mathrm{E}_{2}$ and COX-2 activity. It has been shown that $\mathrm{E}_{2}$ is involved in the induction of COX-2 activity during the D phase, as well as the $\mathrm{P}$ and $\mathrm{E}$ phases of the estrous cycle in rats ${ }^{102}$.

In the rat, PGs, including $\mathrm{PGI}_{2}$ (prostacyclin), $\mathrm{PGF}_{2 \alpha}$, and $\mathrm{PGE}_{2}$, play a significant role in the decidualization response ${ }^{96,103}$. $\mathrm{PGI}_{2}$ is thought to be a key player, but $\mathrm{PGE}_{2}$ has been shown to act on four different $G$ protein receptors. Both COX-1 and COX-2 are found in the epithelial cells of the endometrium and smooth muscle cells in the circular layer of the myometrium; expression of COX-2 in the latter cells increases with IL- $1 \beta$ treatment ${ }^{104}$. Further, COX-1 and 
COX-2 proteins are increased from the non-pregnant D phase stage to day 18 of gestation, supporting the role of COX-2 in decidualization during early pregnancy. As noted in mice, p38 MAPK most likely mediates the decidualization process.

IGFBP-1 is a major secretory product in NHP decidualized endometrium. It plays a role in trophoblast invasion as it can stimulate (in the presence of cAMP) or inhibit (in the absence of cAMP) decidualization ${ }^{48,105}$. In the rat, it has also been shown to be associated with implantation, modulating the proliferation of uterine cells and their production of $\mathrm{PGI}_{2}$ during the peri-implantation period $^{106}$. In the baboon, it is known that both p38 and NF$\kappa \mathrm{B}$ are activated during decidualization, followed by COX-2 and MMP-3 gene expression, which leads to extracellular matrix degradation, disruption of the cytoskeleton, and ultimately, IGFBP-1 production ${ }^{107}$. A similar MAPK mechanism may be acting in rats.

\section{Roles of p38 MAPKs Modulation During Pregnancy and Parturition}

$\mathrm{P}_{4}$ maintains the myometrium of the uterus in a state of quiescence during pregnancy by: 1) inhibiting the expression of contraction associated proteins (CAPs), which include connexin 43 and OTR ${ }^{108}$ and 2) controlling $\mathrm{PGF}_{2 \alpha}$, in part, via modulation of PG dehydrogenase and COX activity ${ }^{109}$. These possible roles for p38 have been previously discussed.

IL- $\beta$ contributes to parturition, by stimulating the production of $\mathrm{PGF}_{2 \alpha}$ via a COX-2-mediated mechanism. As in the normal cycle, $\mathrm{PGF}_{2 \alpha}$ induces contraction and luteolysis. Takanami-Ohnishi et al. have shown, using human decidual stromal cells, that this process is mediated by p38 kinase ${ }^{22}$. Both COX-1 and COX-2 are differentially expressed in the rat uterus, specifically in the epithelial and myometrial cells, during the estrous cycle, increasing dramatically during parturition and pregnancy ${ }^{104}$. Markedly up-regulated p38 MAPK activity has also been demonstrated in the uterus of term-pregnant non-laboring and spontaneously laboring women.

\section{Role of p38 MAPKs in Female Reproductive Pathology}

A variety of intracellular signals, including those involving ER $\alpha$, c-fos, and $\mathrm{p} 38 \alpha$, orchestrate physiological events in the uterus during the secretory and proliferative phases of the estrous cycle in humans and NHPs. It is suggested that p38 has a modulatory role on human endometrial stromal cell proliferation and differentiation ${ }^{81}$. It is known that MAPKs play a role in regulating cellular hypertrophy and hyperplasia via mechanical stretch of the uterus $^{15}$. Therefore, p38 inhibitors could play a role in various uterine and cervical proliferative conditions and cancers, including the pathophysiology of endometriosis ${ }^{24,110}$, endometrial, mammary, and ovarian cancers $^{111-113}$, leiomyoma, and uterine fibroids ${ }^{114,115}$.
MAPKs are known to regulate COX-2 expression and therefore, cervical cancers ${ }^{116}$.

\section{Conclusions}

Toxicologists and toxicologic pathologists need to consider species differences when evaluating the effects of new pharmacologic agents on the female reproductive system. Experiments conducted on different preclinical species are not strictly comparable to that of humans because of significant interspecies differences in the physiology of uterine cyclicity. p38 MAPK signal transduction pathways are interconnected with ER, c-fos, c-jun and jun kinase, and regulate various aspects of the mammalian estrous and menstrual cycles, early pregnancy, and parturition. p38 is involved in: 1) the OT-OTR-mediated events and luteolysis, 2) regulation of uterine tissue breakdown and regeneration, 3) $E_{2}$-induced uterine cell proliferation and growth, 4) implantation and uterine receptivity, and 5) maintenance of uterine quiescence during pregnancy and onset of parturition. Finally, p38 MAPK signaling plays a role in various pathological conditions in the female reproductive tract.

\section{References}

1. Lee JC, Kumar S, Griswold DE, Underwood DC, Votta BJ, and Adams JL. Inhibition of p38 MAP kinase as a therapeutic strategy. Immunopharmacology. 47: 185-201. 2000.

2. Ono $\mathrm{K}$ and Han J. The p38 signal transduction pathway: activation and function. Cell Signal. 12: 1-13. 2000.

3. Zarubin $\mathrm{T}$ and Han J. Activation and signaling of the $\mathrm{p} 38$ MAP kinase pathway. Cell Res. 15: 11-18. 2005.

4. O'Keefe SJ, Mudgett JS, Cupo S, Parsons JN, Chartrain NA, Fitzgerald C, Chen S-L, Lowitz K, Rasa C, Visco D, Luell S, Carballo-Jane E, Owens K, and Zaller DM. Chemical genetics define the roles of p38 alpha and p38 beta in acute and chronic inflammation. J Biol Chem. 282: 34663-34671. 2007.

5. Yang S, Fang Z, Suzuki T, Sasano H, Zhou J, Gurates B, Tamura M, Ferrer K, and Bulun S. Regulation of aromatase P450 expression in endometriotic and endometrial stromal cells by CCAAT/enhancer binding proteins (C/EBPs): decreased C/EBPbeta in endometriosis is associated with overexpression of aromatase. J Clin Endocrinol Metab. 87: 2336-2345. 2002.

6. Pohnke Y, Schneider-Merck T, Fahnenstich J, Kempf R, Christian M, Milde-Langosch K, Brosens JJ, and Gellersen B. Wild-type p53 protein is up-regulated upon cyclic adenosine monophosphate-induced differentiation of human endometrial stromal cells. J Clin Endocrinol Metab. 89: 5233-5244. 2004.

7. Hirota Y, Osuga Y, Hirata T, Koga K, Yoshino O, Harada M, Morimoto C, Nose E, Yano T, Tsutsumi O, and Taketani Y. Evidence for the presence of protease-activated receptor 2 and its possible implication in remodeling of human endometrium. J Clin Endocrinol Metab. 90: 1662-1669. 2005.

8. Kang YJ, Chen J, Otsuka M, Mols J, Ren S, Wang Y, and 
Han J. Macrophage Deletion of p38 alpha Partially Impairs Lipopolysaccharide-Induced Cellular Activation. J Immunol. 180: 5075-5082. 2008.

9. Mihara K, Almansa C, Smeets RL, Loomans EE, Dulos J, Vink PM, Rooseboom M, Kreutzer H, Cavalcanti F, Boots AM, and Nielssen RL. A potent and selective p38 inhibitor protects against bone damage in murine collagen-induced arthritis: a comparison with neutralization of mouse TNFalpha. Br J Pharmacol. 154: 153-164. 2008.

10. Boldt $\mathrm{S}$ and Kolch W. Targeting MAPK signaling: Prometheus' fire or Pandora's box? Curr Pharm Des. 10: 1885-1905. 2004.

11. Radi ZA and Khan NK. Comparative expression and distribution of c-fos, estrogen receptor alpha, and p38 alpha in the uterus of rats, monkeys, and humans. Tox Pathol. 34: 327-335. 2006.

12. Yoshino O, Osuga Y, Hirota Y, Koga K, Hirata T, Yano T, Ayabe T, Tsutsumi O, and Taketani Y. Endometrial stromal cells undergoing decidualization down-regulate their properties to produce proinflammatory cytokines in response to interleukin-1 beta via reduced p38 mitogenactivated protein kinase phosphorylation. J Clin Endocrinol Metab. 88: 2236-2241. 2003.

13. Papa M, Mezzogiorno V, Bresciani F, and Weisz A. Estrogen induces c-fos expression specifically in the luminal and glandular epithelia of adult rat uterus. Biochem Biophys Res Commun. 175: 480-485. 1991.

14. Whitmarsh AJ and Davis RJ. Transcription factor AP-1 regulation by mitogen-activated protein kinase signal transduction pathways. J Mol Med. 74: 589-607. 1996.

15. Oldenhof AD, Shynlova OP, Liu M, Langille BL, and Lye SJ. Mitogen-activated protein kinases mediate stretchinduced c-fos mRNA expression in myometrial smooth muscle cells. Am J Physiol Cell Physiol. 283: C1530-1539. 2002.

16. Roux PP and Blenis J. ERKand p38 MAPK-activated protein kinases: a family of protein kinases with diverse biological functions. Microbiol Mol Biol Rev. 68: 320-344. 2004.

17. Quarmby VE and Korach KS. The influence of 17 betaestradiol on patterns of cell division in the uterus. Endocrinology. 114: 694-702. 1984.

18. Mendoza-Rodriguez CA, Merchant-Larios H, SeguraValdez ML, Moreno-Mendoza N, Cruz ME, Arteaga-Lopez P, Camacho-Arroyo I, Deminguez R, and Cerbon M. c-fos and estrogen receptor gene expression pattern in the rat uterine epithelium during the estrous cycle. Mol Reprod Dev. 64: 379-388. 2003.

19. Weisz A and Bresciani F. Estrogen induces expression of cfos and c-myc protooncogenes in rat uterus. Mol Endocrinol. 2: 816-824. 1988.

20. Bigsby RM and Li A. Differentially regulated immediate early genes in the rat uterus. Endocrinology. 134: 18201826. 1994.

21. Nephew KP, Peters GA, and Khan SA. Cellular localization of estradiol-induced c-fos messenger ribonucleic acid in the rat uterus: c-fos expression and uterine cell proliferation do not correlate strictly. Endocrinology. 136: 3007-3015. 1995.

22. Takanami-Ohnishi Y, Asada S, Tsunoda H, Fukamizu A, Goto K, Yoshikawa H, Kubo T, Sudo T, Kimura S, and Kasuya Y. Possible involvement of p38 mitogen-activated protein kinase in decidual function in parturition. Biochem
Biophys Res Commun. 288: 1155-1161. 2001

23. Otun HA, MacDougall MW, Bailey J, Europe-Finner GN, and Robson SC. Spatial and temporal expression of the myometrial mitogen-activated protein kinases p38 and ERK1/2 in the human uterus during pregnancy and labor. $\mathrm{J}$ Soc Gynecol Investig. 12: 185-190. 2005.

24. Yoshino O, Osuga Y, Hirota Y, Koga K, Hirata T, Harada M, Morimoto C, Yano T, Nishii O, Tsutsumi O, and Taketani Y. Possible pathophysiological roles of mitogenactivated protein kinases (MAPKs) in endometriosis. Am J Reprod Immunol. 52: 306-311. 2004.

25. Scherle PA, Ma W, Lim H, Dey SK, and Trzaskos JM. Regulation of cyclooxygenase-2 induction in the mouse uterus during decidualization. An event of early pregnancy. J Biol Chem. 275: 37086-37092. 2000.

26. Maizels ET, Mukherjee A, Sithanandam G, Peters CA, Cottom J, Mayo KE, and Hunzicker-Dunn M. Developmental regulation of mitogen-activated protein kinase-activated kinases-2 and -3 (MAPKAPK-2/-3) in vivo during corpus luteum formation in the rat. Mol Endocrinol. 15: 716-733. 2001.

27. Shiota M, Sugai N, Tamura M, Yamaguchi R, Fukushima N, Miyano T, and Miyazaki H. Correlation of mitogenactivated protein kinase activities with cell survival and apoptosis in porcine granulosa cells. Zoolog Sci. 20: 193201. 2003

28. Uma J, Muraly P, Verma-Kumar S, and Medhamurthy R. Determination of onset of apoptosis in granulosa cells of the preovulatory follicles in the bonnet monkey (Macaca radiata): correlation with mitogen-activated protein kinase activities. Biol Reprod. 69: 1379-1387. 2003.

29. Wang $\mathrm{H}$ and Stjernholm YV. Plasma membrane receptor mediated MAPK signaling pathways are activated in human uterine cervix at parturition. Reprod Biol Endocrinol. 5: 3. 2007.

30. Yuan Y and Foley G. Handbook of Toxicologic Pathology. W Haschek, C Rousseux, and W Walling (eds). Female reproductive system, vol. 2, Academic Press, San Diego, California. 47-894 and 1706. 2002.

31. Marusak RA, Radi ZA, and Obert L. Expression of Ki-67 in the uterus during various stages of the estrous cycle in rats. Exp Toxicol Pathol. 59: 151-155. 2007.

32. Clark JH and Peck EJJ. Control of estrogen receptor levels by progesterone and its relationship to estrogen antagonism. In: Monographs on Endocrinology. F Gross, M Grumbach, A Labharf, MB Lipsett, T Mann, LT Samuel, and J Zander (eds). New York, Springer-Verlag New York, LLC. 245. 1980.

33. Okulicz WC, Balsamo M, and Tast J. Progesterone regulation of endometrial estrogen receptor and cell proliferation during the late proliferative and secretory phase in artificial menstrual cycles in the rhesus monkey. Biol Reprod. 49: 24-32. 1993.

34. Grazzini E, Guillon G, Mouillac B, and Zingg $\mathrm{HH}$. Inhibition of oxytocin receptor function by direct binding of progesterone. Nature. 392: 509-512. 1998.

35. Gimpl G and Fahrenholz F. The oxytocin receptor system: structure, function, and regulation. Physiol Rev. 81: 629683. 2001.

36. Carson DD, Bagchi I, Dey SK, Enders AC, Fazleabas AT, Lessey BA, and Yoshinaga K. Embryo implantation. Dev Biol. 223: 217-237. 2000. 
37. Poyser NL. The control of prostaglandin production by the endometrium in relation to luteolysis and menstruation. Prostaglandins Leukot Essent Fatty Acids. 53: 147-195. 1995.

38. Chen B, Pan H, Zhu L, Deng Y, and Pollard JW. Progesterone inhibits the estrogen-induced phosphoinositide 3-kinase $->$ AKT $\longrightarrow$ GSK-3beta $\longrightarrow$ cyclin D1 $\rightarrow$ pRB pathway to block uterine epithelial cell proliferation. Mol Endocrinol. 19: 1978-1990. 2005.

39. Lessey BA. Two pathways of progesterone action in the human endometrium: implications for implantation and contraception. Steroids. 68: 809-815. 2003.

40. Srinivasan KR, Blesson CS, Fatima I, Kitchlu S, Jain SK, Mehrotra PK, and Dwivedi A. Expression of alpha(V)beta(3) integrin in rat endometrial epithelial cells and its functional role during implantation. Gen Comp Endocrinol. 160: 124-133. 2009.

41. Thienel T, Chwalisz K, and Winterhager E. Expression of MAPkinases (Erk1/2) during decidualization in the rat: regulation by progesterone and nitric oxide. Mol Hum Reprod. 8: 465-474. 2002.

42. Mulac-Jericevic B, Mullinax RA, DeMayo FJ, Lydon JP, and Conneely OM. Subgroup of reproductive functions of progesterone mediated by progesterone receptor-B isoform. Science. 289: 1751-1754. 2000.

43. Casals G, Ordi J, Creus M, Fabreques F, Casamitjana R, Quinto L, Campo E, Balasch J. Osteopontin and alpha v beta3 integrin expression in the endometrium of infertile and fertile women. Reprod Biomed Online. 16: 808-816. 2008.

44. Abbott DH, Foong SC, Barnett DK, and Dumesic DA. Nonhuman primates contribute unique understanding to anovulatory infertility in women. ILLAR J. 45: 116-131. 2004.

45. Archer DF. Role of the nonhuman primate for research related to women's health. ILLAR J. 45: 212-219. 2004.

46. Crum CP. The female genital tract. In: Robbins Pathologic Basis of Disease. R Cotran, V Kumar, and T Collins (eds). $6^{\text {th }}$ ed., W. B. Saunders Company, Philadelphia, Pennsylvania. 1054-1055. 1999.

47. Okulicz WC, Ace CI, Longcope C, and Tast J. Analysis of differential gene regulation in adequate versus inadequate secretory-phase endometrial complementary deoxyribonucleic acid populations from the rhesus monkey. Endocrinology. 137: 4844-4850. 1996.

48. Strakova Z, Szmidt M, Srisuparp S, and Fazleabas AT. Inhibition of matrix metalloproteinases prevents the synthesis of insulin-like growth factor binding protein-1 during decidualization in the baboon. Endocrinology. 144: 5339-5346. 2003.

49. Kliman HJ. Uteroplacental blood flow. The story of decidualization, menstruation, and trophoblast invasion. Am J Pathol. 157: 1759-1768. 2000.

50. Auletta FJ, Paradis DK, Wesley M, and Duby RT. Oxytocin is luteolytic in the rhesus monkey (Macaca mulatta). $\mathrm{J}$ Reprod Fertil. 72: 401-406. 1984.

51. Sugino N, Karube-Harada A, Taketani T, Sakata A, and Nakamura Y. Withdrawal of ovarian steroids stimulates prostaglandin F2alpha production through nuclear factorkappaB activation via oxygen radicals in human endometrial stromal cells: potential relevance to menstruation. J Reprod Dev. 50: 215-225. 2004.
52. Orsi NM and Tribe RM. Cytokine networks and the regulation of uterine function in pregnancy and parturition. $\mathrm{J}$ Neuroendocrinol 20: 462-469. 2008.

53. Senger PL. Pathways to Pregnancy and Parturition. Pullman (ed). Current Conceptions, Inc. 330. 2003.

54. Korzekwa AJ, Jaroszewski JJ, Woclawek-Potocka I, Bah MM, and Skarzynski DJ. Luteolytic Effect of Prostaglandin F(2alpha) on Bovine Corpus Luteum Depends on Cell Composition and Contact. Reprod Domest Anim. 43: 462472. 2008.

55. Murata T, Narita K, Honda K, and Higuchi T. Changes of receptor mRNAs for oxytocin and estrogen during the estrous cycle in rat uterus. J Vet Med Sci. 65: 707-712. 2003.

56. Hoare S, Copland JA, Strakova Z, Ives K, Jeng YJ, Hellmich MR, and Soloff MS. The proximal portion of the $\mathrm{COOH}$ terminus of the oxytocin receptor is required for coupling to g(q), but not g(i). Independent mechanisms for elevating intracellular calcium concentrations from intracellular stores. J Biol Chem. 274: 28682-28689. 1999.

57. Lubahn DB, Moyer JS, Golding TS, Couse JF, Korach KS, and Smithies O. Alteration of reproductive function but not prenatal sexual development after insertional disruption of the mouse estrogen receptor gene. Proc Natl Acad Sci USA. 90: 11162-11166. 1993.

58. Kuiper GG, Carlsson B, Grandien K, Enmark E, Haggblad J, Nilsson S, and Gustafsson JA. Comparison of the ligand binding specificity and transcript tissue distribution of estrogen receptors alpha and beta. Endocrinology. 138: 863870. 1997.

59. Lessey BA, Killam AP, Metzger DA, Haney AF, Greene GL, and McCarty KS, Jr. Immunohistochemical analysis of human uterine estrogen and progesterone receptors throughout the menstrual cycle. J Clin Endocrinol Metab. 67: 334-340. 1988.

60. Kuiper GG, Enmark E, Pelto-Huikko M, Nilsson S, and Gustafsson JA. Cloning of a novel receptor expressed in rat prostate and ovary. Proc Natl Acad Sci USA. 93: 59255930. 1996.

61. Matsuzaki S, Fukaya T, Suzuki T, Murakami T, Sasano H, and Yajima A. Oestrogen receptor alpha and beta mRNA expression in human endometrium throughout the menstrual cycle. Mol Hum Reprod. 5: 559-564. 1999.

62. Hiroi H, Inoue S, Watanabe T, Goto W, Orimo A, Momoeda M, Tsutsumi O, Taketani Y, and Muramatsu H. Differential immunolocalization of estrogen receptor alpha and beta in rat ovary and uterus. J Mol Endocrinol. 22: 37-44. 1999.

63. Pietras RJ and Szego CM. Specific binding sites for oestrogen at the outer surfaces of isolated endometrial cells. Nature. 265: 69-72. 1977.

64. Razandi M, Pedram A, Greene GL, and Levin ER. Cell membrane and nuclear estrogen receptors (ERs) originate from a single transcript: studies of ER alpha and ER beta expressed in Chinese hamster ovary cells. Mol Endocrinol. 13: 307-319. 1999.

65. Acconcia F, Totta P, Ogawa S, Cardillo I, Inoue S, Leone S, Trentalance A, Muramatsu M, and Marino M. Survival versus apoptotic 17 beta-estradiol effect: role of ER alpha and ER beta activated non-genomic signaling. J Cell Physiol. 203: 193-201. 2005.

66. West NB and Brenner RM. Estrogen receptor levels in the oviducts and endometria of cynomolgus macaques during 
the menstrual cycle. Biol Reprod. 29: 1303-1312. 1983.

67. Ozaki T, Takahashi K, Kanasaki H, and Miyazaki K. Expression and activation of mitogen-activated protein kinase in the human endometrium during the menstrual cycle. Am J Obstet Gynecol. 195: 1343-1350. 2006.

68. Lee $\mathrm{H}$ and Bai $\mathrm{W}$. Regulation of estrogen receptor nuclear export by ligand-induced and p38-mediated receptor phosphorylation. Mol Cell Biol. 22: 5835-5845. 2002.

69. Lee H, Jiang F, Wang Q, Nicosia SV, Yang J, Su B, and Bai W. MEKK1 activation of human estrogen receptor alpha and stimulation of the agonistic activity of 4hydroxytamoxifen in endometrial and ovarian cancer cells. Mol Endocrinol. 14: 1882-1896. 2000.

70. Hall JM and McDonnell DP. Coregulators in nuclear estrogen receptor action: from concept to therapeutic targeting. Mol Interv. 5: 343-357. 2005.

71. Anter E, Chen K, Shapira OM, Karas RH, and Keaney JF, Jr. p38 mitogen-activated protein kinase activates eNOS in endothelial cells by an estrogen receptor alpha-dependent pathway in response to black tea polyphenols. Circ Res. 96: 1072-1078. 2005.

72. Bunone G, Briand PA, Miksicek RJ, and Picard D. Activation of the unliganded estrogen receptor by EGF involves the MAP kinase pathway and direct phosphorylation. Embo J. 15: 2174-2183. 1996.

73. Shao D, Rangwala SM, Bailey ST, Krakow SL, Reginato MJ, and Lazar MA. Interdomain communication regulating ligand binding by PPAR-gamma. Nature. 396: 377-380. 1998.

74. Sherr CJ. G1 phase progression: cycling on cue. Cell. 79: 551-555. 1994

75. Yamashita S, Takayanagi A, and Shimizu N. Temporal and cell-type specific expression of c-fos and c-jun protooncogenes in the mouse uterus after estrogen stimulation. Endocrinology. 137: 5468-5475. 1996.

76. Inoue E, Hanai M, Yamada K, Esashi T, and Yamauchi J. Transcriptional coactivator $\mathrm{p} 300 / \mathrm{CBP}$-associated factor and p300/CBP-associated factor type B are required for normal estrogen response of the mouse uterus. Biosci Biotechnol Biochem. 68: 2209-2211. 2004.

77. Huet-Hudson YM, Andrews GK, and Dey SK. Cell typespecific localization of c-myc protein in the mouse uterus: modulation by steroid hormones and analysis of the periimplantation period. Endocrinology. 125: 1683-1690. 1989.

78. Fujimoto J, Hori M, Ichigo S, Nishigaki M, and Tamaya $T$. Tissue differences in the expression of mRNAs of Ha-ras, cmyc, fos and jun in human uterine endometrium, myometrium and leiomyoma under the influence of estrogen/progesterone. Tumor Biol. 15: 311-317. 1994.

79. Salmi A and Rutanen FM. C-fos and c-jun expression in human endometrium and myometrium. Mol Cell Endocrinol. 117: 233-240. 1996.

80. Bircan S, Ensari A, Ozturk S, Erdogan N, Dundar I, and Ortac F. Immunohistochemical analysis of c-myc, c-jun and estrogen receptor in normal, hyperplastic and neoplastic endometrium. Pathol Oncol Res. 11: 32-39. 2005.

81. Hong IS, Kim SH, Koong MK, Jun JH, Lee YS, and Kang KS. Roles of p38 and c-jun in the differentiation, proliferation and immortalization of normal human endometrial cells. Hum Reprod. 19: 2192-2199. 2004.

82. Karin M, Liu Z, and Zandi E. AP-1 function and regulation.
Curr Opin Cell Biol. 9: 240-246. 1997.

83. Humar M, Loop T, Schmidt R, Hoetzel A, Roesslein M, Andriopoulos N, Pahl HL, Geiger KK, Pannen BH. The mitogen-activated protein kinase p38 regulates activator protein 1 by direct phosphorylation of c-Jun. Int J Biochem Cell Biol. 39: 2278-2288. 2007.

84. Wang Y, Feng H, Bi C, Zhu L, Pollard JW, and Chen B. GSK-3beta mediates in the progesterone inhibition of estrogen induced cyclin D2 nuclear localization and cell proliferation in cyclin D1-/- mouse uterine epithelium. FEBS Lett. 581: 3069-3075. 2007.

85. Shiozawa $T$, Miyamoto $T$, Kashima H, Nakayama K, Nikaido T, and Konishi I. Estrogen-induced proliferation of normal endometrial glandular cells is initiated by transcriptional activation of cyclin D1 via binding of c-Jun to an AP-1 sequence. Oncogene. 23: 8603-8610. 2004.

86. Cameo P, Srisuparp S, Strakova Z, and Fazleabas AT. Chorionic gonadotropin and uterine dialogue in the primate. Reprod Biol Endocrinol. 2: 50. 2004.

87. Bazer FW, Burghardt RC, Johnson GA, Spencer TE, and Wu G. Interferons and progesterone for establishment and maintenance of pregnancy: interactions among novel cell signaling pathways. Reprod Biol. 8: 179-211. 2008.

88. Stavreus-Evers A, Nikas G, Sahlin L, Eriksson H, and Landgren BM. Formation of pinopodes in human endometrium is associated with the concentrations of progesterone and progesterone receptors. Fertil Steril. 76: 782-791. 2001.

89. Slayden OD and Keator CS. Role of progesterone in nonhuman primate implantation. Semin Reprod Med. 25: 418-430. 2007.

90. Yoshino O, Osuga Y, Koga K, Hirota Y, Hirata T, Ruimeng X, Na L, Yano T, Tsutsumi O, and Taketani Y. FR 167653, a p38 mitogen-activated protein kinase inhibitor, suppresses the development of endometriosis in a murine model. $\mathrm{J}$ Reprod Immunol. 72: 85-93. 2006.

91. Fazleabas AT, Kim JJ, and Strakova Z. Implantation: embryonic signals and the modulation of the uterine environment. Placenta. 25 (Suppl A): S26-31. 2004.

92. Kim S, Choi Y, Spencer TE, and Bazer FW. Effects of the estrous cycle, pregnancy and interferon tau on expression of cyclooxygenase two (COX-2) in ovine endometrium. Reprod Biol Endocrinol. 1: 58. 2003.

93. Guzeloglu A, Subramaniam P, Michel F, and Thatcher WW. Interferon-tau induces degradation of prostaglandin $\mathrm{H}$ synthase-2 messenger RNA in bovine endometrial cells through a transcription-dependent mechanism. Biol Reprod. 71: 170-176. 2004.

94. Bigonnesse F, Labelle Y, and Akoum A. Triphasic expression of interleukin-1 receptor type I in human endometrium throughout the menstrual cycle of fertile women and women with unexplained infertility. Fertil Steril. 75: 79-87. 2001.

95. Ross JW, Malayer JR, Ritchey JW, and Geisert RD. Characterization of the interleukin-1beta system during porcine trophoblastic elongation and early placental attachment. Biol Reprod. 69: 1251-1259. 2003.

96. Kennedy TG and Doktorcik PE. Effects of analogues of prostaglandin E2 and F2 alpha on the decidual cell reaction in the rat. Prostaglandins. 35: 207-219. 1988.

97. Jacobs AL and Carson DD. Uterine epithelial cell secretion of interleukin-1 alpha induces prostaglandin E2 (PGE2) and 
PGF2 alpha secretion by uterine stromal cells in vitro. Endocrinology. 132: 300-308. 1993.

98. Papay KD and Kennedy TG. Characterization of temporal and cell-specific changes in transcripts for prostaglandin $\mathrm{E}(2)$ receptors in pseudopregnant rat endometrium. Biol Reprod. 62: 1515-1525. 2000.

99. Radi ZA. Pathophysiology of cyclooxygenase inhibition in animal models. Tox Pathol. 37: 34-46. 2009

100. Lim H, Paria BC, Das SK, Dinchuk JE, Langenbach R, Trzaskos JM, and Dey S. Multiple female reproductive failures in cyclooxygenase 2-deficient mice. Cell. 91: 197208. 1997.

101. Evans J, Catalano RD, Morgan K, Critchley HO, Millar RP, and Jabbour HN. Prokineticin 1 signaling and gene regulation in early human pregnancy. Endocrinology. 149: 2877-2887. 2008.

102. Nishijima M, Katori $M$, and Yamamoto S. Induction of cyclooxygenase type-2 (COX-2) in rat endometrium at the peak of serum estradiol during the estrus cycle. Jpn J Pharmacol. 69: 289-291. 1995.

103. Cong J, Diao HL, Zhao YC, Ni H, Yan YQ, and Yang ZM. Differential expression and regulation of cylooxygenases, prostaglandin E synthases and prostacyclin synthase in rat uterus during the peri-implantation period. Reproduction. 131: 139-151. 2006.

104. Dong YL, Gangula PR, Fang L, and Yallampalli C. Differential expression of cyclooxygenase- 1 and -2 proteins in rat uterus and cervix during the estrous cycle, pregnancy, labor and in myometrial cells. Prostaglandins. 52: 13-34. 1996.

105. Strakova Z, Srisuparp S, and Fazleabas AT. IL-1beta during in vitro decidualization in primate. J Reprod Immunol. 55: 35-47. 2002.

106. Tamura K, Hara T, Kutsukake M, Iwatsuki K, Yanagida M, Yoshie M, and Kogo H. Expression and the biological activities of insulin-like growth factor-binding protein related protein 1 in rat uterus during the periimplantation period. Endocrinology. 145: 5243-5251. 2004.

107. Strakova Z, Srisuparp S, and Fazleabas AT. Interleukin1beta induces the expression of insulin-like growth factor binding protein-1 during decidualization in the primate. Endocrinology. 141: 4664-4670. 2000.

108. Mitchell JA, Ting TC, Wong S, Mitchell BF, and Lye SJ. Parathyroid hormone-related protein treatment of pregnant rats delays the increase in connexin 43 and oxytocin receptor expression in the myometrium. Biol Reprod. 69: 556-562. 2003.

109. Farina M, Ribeiro ML, Weissmann C, Estevez A, Billi S, Vercelli C, and Franchi A. Biosynthesis and catabolism of prostaglandin F2alpha (PGF2 alpha) are controlled by progesterone in the rat uterus during pregnancy. J Steroid
Biochem Mol Biol. 91: 211-218. 2004.

110. Hirata T, Osuga Y, Hamasaki K, Yoshino O, Ito M, Hasegawa A, Takemura Y, Hirota Y, Nose E, Morimoto C, Harada M, Koga K, Tajima T, Saito S, Yano T, and Taketani Y. Interleukin (IL)-17A stimulates IL-8 secretion, cyclooxygensase-2 expression, and cell proliferation of endometriotic stromal cells. Endocrinology. 149: 1260 1267. 2008.

111. Sakamoto T, Eguchi H, Omoto Y, Ayabe T, Mori H, and Hayashi S. Estrogen receptor-mediated effects of tamoxifen on human endometrial cancer cells. Mol Cell Endocrinol. 192: 93-104. 2002.

112. Kim KY, Choi KC, Park SH, Chou CS, Auersperg N, and Leung PC. Type II gonadotropin-releasing hormone stimulates p38 mitogen-activated protein kinase and apoptosis in ovarian cancer cells. J Clin Endocrinol Metab. 89: 3020-3026. 2004.

113. Gauthier ML, Pickering CR, Miller CJ, Fordyce CA, Chew KL, Berman HK, and Tlsty TD. p38 regulates cyclooxygenase-2 in human mammary epithelial cells and is activated in premalignant tissue. Cancer Res. 65: 17921799. 2005.

114. Ding L, Xu J, Luo X, and Chegini N. Gonadotropin releasing hormone and transforming growth factor beta activate mitogen-activated protein kinase/extracellularly regulated kinase and differentially regulate fibronectin, type I collagen, and plasminogen activator inhibitor-1 expression in leiomyoma and myometrial smooth muscle cells. J Clin Endocrinol Metab. 89: 5549-5557. 2004.

115. Levens E, Luo X, Ding L, Williams RS, and Chegini N. Fibromodulin is expressed in leiomyoma and myometrium and regulated by gonadotropin-releasing hormone analogue therapy and TGF-beta through Smad and MAPK-mediated signaling. Mol Hum Reprod. 11: 489-494. 2005.

116. Kulkarni S, Rader JS, Zhang F, Liapis H, Koki AT, Masferrer JL, Subbaramaiah K, and Dannenberg AJ. Cyclooxygenase-2 is overexpressed in human cervical cancer. Clin Cancer Res. 7: 429-434. 2001.

117. Pritchett KR and Coming BF. Biology and Medicine of Rats. JD Reuter, and MA Suckow (eds). Ithaca. International Veterinary Information Service. B2503.0904. 2004.

118. Rehm S, Stanislaus DJ, and Williams AM. Estrous cycledependent histology and review of sex steroid receptor expression in dog reproductive tissues and mammary gland and associated hormone levels. Birth Defects Res B Dev Reprod Toxicol. 80: 233-245, 2007.

119. Draft OECD guidance for endocrine disruption: a guidance document for histologic evaluation of endocrine and reproductive testes. http://www.oecd.org/document/12/ 0,3343,en_2649_34377_1898188_1_1_1_1,00.html 